This is an Accepted Manuscript of an article published by Taylor \& Francis in European Journal of the History of Economic Thought on 8 July 2019, available online: http://www.tandfonline.com/10.1080/09672567.2019.1635180 


\title{
Circular Reasoning. Forbonnais and the intricate history of circular flow analysis in the 1750s
}

\author{
Richard van den Berg
}

\section{Introduction}

In his essay 'Of Public Credit' of 1752 David Hume remarked upon a term that in the commercial literature of his time was both ubiquitous and obscure:

There is a word, which is here in the mouth of every body, and which, I find, has also got abroad, and is much employed by foreign writers*, in imitation of the English; and that is CIRCULATION. This word serves as an account of every thing; and tho'I confess, that I have sought for its meaning in the present subject, ever since I was a school-boy, I have never yet been able to discover it.

The 'foreign writers' Hume had in mind, he explained in a footnote, were 'Melon, Du Tot, Law'. ${ }^{1}$ These influential authors had indeed frequently used the word 'circulation' in their works, as had British authors left unnamed by Hume, since the last decades of the $17^{\text {th }}$ century. ${ }^{2}$ He was, however, also largely correct to say that those earlier authors rarely bothered to define the term or to develop clear conceptions of the precise economic circuits they imagined. ${ }^{3}$ It was as if 'circulation' was understood as a word so common and all-encompassing that it was found scarcely necessary to define it. To illustrate this point, one looks in vain for entries on 'Circulation' in dictionaries specializing in the knowledge of trade that date from before the mid-century. The most important of these, Savary des Brûlons's Dictionnaire Universel de Commerce, first published in 1723, silently moved on from 'Cirage' to 'Cire' (Savary 1723, I, p.778).4

\footnotetext{
1 This passage was omitted from editions of Hume's Political Discourses from 1770 onwards. Hence it did not feature in most modern editions (See Hume 1955, pp.92-3). In the French translations of 1754 (p. 147) and 1767 (p.186) the passage was included.

2 Melon (1736) used the term 'circulation' prominently especially in chapter 24 on English political arithmetic. Dutot (1738) also frequently emphasised the importance of the uninterrupted circulation of money. See for example, article vii (vol 2, pp.289-94). Historians have highlighted the widespread use of the term in the $18^{\text {th }}$ century since at least Monroe (1923, pp.272-89), Heckscher (1935, 2, pp. 217-21) and Viner (1937, pp.36-40).

3 Some modern students who would disagree with this statement are Nagels (1970) and BenitezRochel and Robles-Teigeiro (2003) who have argued, in their own ways, that Boisguilbert developed a systematic analysis of circular flow. Murphy (1993) who has made a similar case for Law. These readings do, however, require significant reconstructive efforts from dispersed passages that gain significance mostly as 'anticipations' of the more developed and systematic reasoning of Cantillon or Quesnay.

4 The fact that Savary did at the same time use the term 'circulation' in a number of places underscores my point about its loose usage. See e.g. the entry 'Banque' pp. 240, 246, 252, 253, 254; the entry 'Billet', p. 342; and the entry 'Commerce de France' p. 838. Another specialized dictionary that went through many editions throughout the $18^{\text {th }}$ century, Chomel's Dictionnaire œeconomique, also did not have an entry on 'circulation'.
} 
Universal lexicographical works of the time did, of course, have entries on 'Circulation'. But these invariably concerned physical and physiological phenomena. For instance, in the groundbreaking Cyclopedia of Ephraim Chambers the relevant entry started:

CIRCULATION the Act of circulating or moving in a Circle. As in the grand World we find a perpetual and orderly Circulation of Waters, convey'd from the Sea by subterraneous Passages, Springs, \&c. and return'd thither again by Rivers \&c. so in the little World, Man, a like Circuit is observ'd; the Blood being continually driven from the Heart, by the Arteries, to all Parts of the Body; and brought back again to the Heart by the Veins (Chambers 1728, vol. 1, p.222).

Modern students have argued that Harvey's discovery of blood circulation acted as a powerful metaphor to a number of $17^{\text {th }}$ century authors for depicting social and economic processes, and one does encounter comparisons of this kind in various commercial writings up to the mid- $18^{\text {th }}$ century. ${ }^{5}$ However, by that time these metaphors appear to have become somewhat tired literary flourishes rather than analysis-inspiring analogies. At least the lack of associations in the leading $18^{\text {th }}$ century dictionaries between physiological and social conceptions of circulation suggests that this had not become an essential trope. ${ }^{6}$

What did happen during the 1750s, however, was that conceptions of circulation started to assume a more central and well-defined role in theories of some prominent economic writers. Without a doubt, the two theorists who are most well-known for bringing a new rigour to circular flow analysis are Richard Cantillon (16?-1734?) and François Quesnay (1694-1774). Indeed, it is a long accepted view that it was Quesnay's reading of Cantillon's Essai sur la nature $d u$ commerce en général which provided the former with the impetus for his eyecatching intellectual innovation of depicting the grand economic process as a circular flow in his Tableaux économiques. ${ }^{7}$

This renewed focus on circular flow as a central conception for conceiving the 'economy as a whole' did, however, not come about, as it has often been portrayed, as 'one strong and simple line of development' (Schumpeter 1954, p.218). A more intricate story needs to be told about the relevant intellectual debates in France during the 1750s and 1760s. In order to tell this story, this paper highlights the neglected content of an entry in Diderot and D'Alembert's Encyclopédie. In this work, the intellectual centrepiece of the French Enlightenment, the relevant discussion is not found in the entry 'Circulation' (volume 3, pp.467-71), which

\footnotetext{
${ }^{5}$ See e.g Eriksen (2017) for the use of the metaphor in the $17^{\text {th }}$ century and see $n .51$ for some $18^{\text {th }}$ century examples.

${ }^{6}$ Cf. note 8 below.

7 The most forceful modern advocate of the direct and very substantial influence remains Schumpeter (1954, especially p.222, pp.239-243). Commentators after Schumpeter, while confirming the influence of the Essai on Quesnay's conception of the Tableaux, have in various ways acknowledged the significant ways in which his analysis differed both in technical details and with regards to the purposes to which it was put. See e.g. Meek (1962, pp.266-9), McNally (1988, pp.95-7), Brewer (2001, p.xix-xxii), (2005), Benitez-Rochel and Robles-Teigeiro (2003).
} 
deals, like Chamber's Cyclopedia, with physiological phenomena. ${ }^{8}$ Instead, it was the entry 'Especes' ('Cash') in volume 5, first published in November 1755 that contained a long subsection with the title De la circulation, du surhaussement \& de l'abaissement des especes. ${ }^{9}$ The author of this contribution, discussed in more detail in section 3 below, was François Véron Duverger de Forbonnais (17221800). It had already appeared one year earlier in almost identical form as chapter 9 of Forbonnais's then famous Elémens du commerce, carrying the shorter title De la circulation de l'argent. ${ }^{10}$

It should be noted that the Encyclopédie was not the first lexicographical work that had an entry (or subsection) on 'Circulation' with an economic content. That distinction goes to Malachy Postlethwayt's British emulation of Savary's Dictionnaire, the Universal Dictionary of Trade and Commerce. Its entry 'Circulation', together with the entry 'Cash', originally published in 1752, provided the kind of precise discussion of the economic notion of 'circulation', the lack of which Hume had bemoaned just months earlier. ${ }^{11}$ Postlethwayt's entry started with a sentence that was reminiscent of the Cyclopedia: 'CIRCULATION, in its common acceptation, signifies the act of moving round, or in a circle' (Postlethwayt 1751-5, i, p.498). But it then went on to focus on a specific kind of circuit:

we may consider the money which goes out of the land-proprietor's pocket, and is spread into several rivulets of barter in circulation; out of which it is again gathered into the farmer's purse, to make another quarter's payment to the land-proprietor (ibid.).

Modern readers know that this nutshell description of the circular flow of money and incomes between different social orders, and the detailed expositions of the same conception that followed it, were taken from a manuscript version of Cantillon's Essay. ${ }^{12}$

\footnotetext{
${ }^{8} \mathrm{~A}$ discussion of the circulation of blood is preceded by the following definition: 'CIRCULATION, s.f. (Gram.) se dit en général de tout mouvement périodique ou non, qui ne se fait point en ligne droit: on dit que le sang circule, que l'espece circule, $\& c^{\prime}$. While therefore at least an analogy is noted in purely linguistic terms between the circulation of blood and money, a cross-reference to the subsection in the entry 'Especes' is, somewhat tellingly, missing.

${ }^{9}$ The entry as a whole runs from page 957 to 970 . The first two pages were written by a M. du Four, about whom little is known. The editors only indicate that he was 'versé dans les matieres de finance'. He also contributed 'douane', 'droits du ro', 'emprunt', 'fer (marque des fers)'.

${ }^{10}$ The editors of the Encyclopédie acknowledged this previous publication when they stated that the subsection was reproduced from 'the treatise on the Elemens du Commerce of M. de Forboney' [sic.] (1755, p.959). To be precise, they reproduced with very few changes the text of the second edition of Elémens. In this respect the entry was different from other contributions by Forbonnais in volumes 3 and 4 of the Encyclopédie. See below n.27.

${ }^{11}$ To be precise, Hume's Political Discourses was published in March 1752. Postlethwayt's entry 'Circulation' occurred in issue 42 of Postlethwayt's Dictionary, which was first published as a separate installment towards the end of October 1752. The closely related entry 'Cash' was included in issue 39, published a little earlier around the beginning of August of the same year.

${ }^{12}$ The Essay had been written around the early 1730s. For a study of Postlethwayt's borrowings from Cantillon and comparisons with other published and manuscript versions of the latter's writings see Cantillon (2015). Support is provided there for the view expressed in the next paragraph that Postlethwayt's borrowings were probably to a large extent verbatim.
} 
Postlethwayt's entries are mentioned here partly for reasons of chronology: his Universal Dictionary made Cantillon's theory of circulation, in all its essential details, readily available in print nearly three years before the publication of the Essai in France in May 1755.13 The other reason is that there was an important difference between the English and French dictionary entries: whereas Postlethwayt merely plagiarized Cantillon's words rather than developing them, Forbonnais was clearly a much more creative writer. Nevertheless, a number of parallels between both men's entries on 'Circulation' suggest that Forbonnais too had been exposed to Cantillon's ideas by early 1754 at the latest, hence prior to the publication of the first French print edition. The likely source, content and creative use of these borrowings is the main topic in what follows.

The reason why Forbonnais's discussions of circulation offer an important additional perspective on the development of circular flow analysis during the high Enlightenment is twofold. First, through its publication in Elémens $d u$ commerce and in the Encyclopédie Forbonnais's discussion of circulation soon received a large, Europe-wide exposure. During the 1750s and 1760s the Elémens du commerce was translated into several continental languages. For about two decades these translations and other adaptations of his writings had a considerable impact on public debates and administrations in Germany, Austria, the Netherlands, Italy, Spain and Portugal. ${ }^{14}$ In fact, it was also translated, twice even, into English and extensive parts were plagiarized by the same Malachy Postlethwayt in two post-dictionary works that were published in $1757 .{ }^{15} \mathrm{In}$

\footnotetext{
${ }^{13}$ It is not impossible that Forbonnais would have had access to this English publication at an early stage. From November 1751 Postlethwayt's Dictionary was published in weekly installments and by November 1753 the issues covering the letters A to K were published in a first volume. This volume was then immediately reviewed in Matthieu Maty's Journal Britannique, a journal that had a Europe-wide francophone readership. There are some indications that Postlethwayt's work soon drew the attention of members of the Gournay circle (see Sabbagh 2016, pp. 29-30 and van den Berg 2017a, p. 1174 and p.1193). As indicated below (n.54 and n.63), there are a few passages in Forbonnais's writings, predating the publication of the first French print edition of Cantillon's Essai, that hint at a possible familiarity with the different version of that writer's words that had appeared in the entry 'Barter' of Postlethwayt's Dictionary. However, it needs to be clearly acknowledged that these few similarities scarcely amount to evidence that could justify any strong claims. Instead, the possibility that Forbonnais had access from about 1753 to a French manuscript version of the Essai seems more likely. As far as Quesnay goes, those of his writings that show resemblances to anything Cantillon wrote postdate the publication of the first French print edition in 1755 and there is very little to suggest that he had actually studied any of Postlethwayt's writings. This is despite a reference dating from 1760 (see Quesnay 2015, p.465) to Postlethwayt (1757a), which also included relevant fragments taken from Cantillon: it appears to be based on the review of that work of Postlethwayt that had appeared in the Journal de Commerce in 1759. This review in turn was a straightforward French translation of an English review that had appeared two years earlier in the Monthly Review (see van den Berg 2017b).

14 This Europe-wide dissemination of Forbonnais's writings is explored in great detail in an excellent set of contributions to a special issue of History of European Ideas of 2014, edited by Antonella Alimento.

${ }^{15}$ As part of far more extensive borrowings from Forbonnais, most of his chapter on circulation was included in English translation as the concluding chapter of Postlethwayt (1757a, pp.332-362) and in anonymous (1767, pp.162-184). I discuss these little known cases of plagiarism from the Elémens in van den Berg (2017b). Its significance for the present paper is twofold. First, Postlethwayt (1757a) actually combined large fragments on monetary theory from Cantillon and Forbonnais, suggesting in that way their compatibility. Although this by itself does not actually prove that Forbonnais had been intellectually indebted to Cantillon, it shows that a contemporary
} 
addition, Forbonnais also benefited from subsequent dispersal of his writings through his activities as an Encyclopédiste. The entry 'Especes', along with others, was soon adopted in the updated Copenhagen edition of Savary's Dictionnaire universel de commerce (1759-65). ${ }^{16}$ In other words, Forbonnais's discussion of circulation, far from being some obscure contribution by a little known author, ${ }^{17}$ may in the eyes of contemporary readers even have been the foremost treatment of the topic.

Second, Forbonnais's monetary ideas kept evolving in subsequent years. This paper traces this evolution in the following way. Section 2 looks at Forbonnais's involvement with Gournay and his circle and examines the former's earliest writings on monetary matters. Section 3 shows that Forbonnais subsequently developed his views on circulation in greater detail in Elémens, partly in response to his reading of Cantillon's Essai. Section 4 discusses the implications of the fact that, after having entertained amicable relations with Quesnay in the late 1750s, by the mid-1760 Forbonnais had turned into a declared opponent of the physiocratic doctrines. Part one of his polemical work against Quesnay, the Principes et Observations aconomiques of 1767, was cast in terms of an alternative theory of circulation. Thus ironically, one conception of circulation, partly inspired by Cantillon, was confronted with another conception of circulation, also partly inspired by Cantillon. Section 5 is a conclusion.

\section{Beginnings}

\subsection{Member of the Gournay circle}

connoisseur like Postlethwayt at least recognized a very strong likeliness. Second, one of the English translations, the one printed anonymously in 1767 (for details again see van den Berg 2017b), is used below for quoting passages from the Elémens. In addition, Postlethwayt (1757a, pp.87-109) also translated a part of Forbonnais's introductory essay to his Négotiant anglois of 1753 , which below is equally used for English quotations.

16 In their foreword to volume 1, dated 1 December 1758, the editors explained that in recent years a wealth of materials had appeared in the famous Dictionnaire Encyclopédique and the Journal Oeconomique and that they had considered it their 'duty to benefit' from this literature. As a result 'Especes' was adopted verbatim in volume 2, pp.375-94, as were several other entries written by Forbonnais. Ten years later Morellet, in the prospectus for what would have been a radically new commercial dictionary, highlighted this borrowing practice by noting that the Copenhagen edition had added a number of 'articles généraux d'économie politique' to the predominantly technical matter of the earlier editions of Savary. In this the Copenhagen edition had followed Postlethwayt's innovation of collating two kinds of commercial knowledge, one technical and one political (see van den Berg 2017a).

17 During the $19^{\text {th }}$ century Forbonnais moved into the blind spot of many historians of political economy. Even well-informed French historians started to neglect Forbonnais. See e.g. de Lavergne (1870) or Espinas (1891). Of course, it is rare for an author to be forgotten completely and the inclusion of the first part of Forbonnais (1767) in the influential series Mélanges $d^{\prime}$ Economie politique made some of his writings available to mid-19 ${ }^{\text {th }}$ century readers. Later French studies like Fleury (1915), Harsin (1928) and Morrisson and Goffin (1967) kept a modest interest going. More sustained interest in Forbonnais's work is of a more recent date. See amongst others Alimento (1985) (2006), (2013), Meyssonnier (1989) (1990), Larrère (1992), van den Berg (2002), Sonenscher (2007), Hont (2008), Orain (2010) (2012) (2013), Demals and Hyard (2015) and Boyer (2017). For literature on the international diffusion of Forbonnais's writings see n.14 above. 
Forbonnais's first economic writings were part of what a contemporary reviewer described as 'a sudden sweep of success' (une gradation rapide de succès) of publications that established the Science of Commerce in France in the first half of the 1750s (Anonymous 1759a, p.39). Thanks to recent scholarship we now know in much greater detail that this outpouring of books and pamphlets was part of an orchestrated campaign by a group of young authors and aspiring administrators tutored and patronized by Jacques Claude Marie Vincent de Gournay (17121759)..$^{18}$ It is not known precisely when Forbonnais first made his acquaintance with Gournay, but it has been suggested that this may have happened in 1748 when the younger man decided to leave his father's textile business and came to Paris in search of a literary and administrative career. ${ }^{19}$ More certain is that by the end of 1752 at the latest Forbonnais had become close enough to Gournay for the latter to allow him to read his manuscripts and insert comments (see Meyssonnier 2008, pp. xlv-xlvii; 2011, p.90). Thus, together with his maternal cousin, LouisJoseph Plumard de Dangeul (1722-1777), Forbonnais was one of the earliest members of the so-called Gournay circle. ${ }^{20}$

This association did not imply any strict adherence to a single set of doctrinal ideas. Instead it involved a shared outlook about the kind of practical reforms required in the administration of trade in France, and also the adoption of a specific literary strategy of changing the minds of men of state, and of the wider lettered public, in favour of such reforms. By and large this strategy was to appraise the commercial, financial and administrative practices of France by comparing them to those of competing nations. More specifically, Gournay initiated a project of translation of a number of foreign books that were believed to embody the commercial wisdom of competitor nations, and of using these as vehicles for reformist commentary.

\footnotetext{
18 The best introduction to the Gournay circle is the set of essays edited by Charles, Lefebvre and Théré (2011). It builds on various studies about this group of authors that have appeared mostly since the pioneering contributions by Tsuda (1983) (1993) and Murphy (1986a), including Meyssonnier (1989) (2008), Larrère (1992), Charles (2006) and Skorniki (2006). In this literature there is agreement that 'membership' of the group is mostly defined by being part of the network of contacts of Gournay and/or having published, during the 1750s, works that on the whole are in line with Gournay's programme for economic and administrative reform. This necessarily loose criterion makes the exact boundaries of the circle somewhat fuzzy. Charles (2011, p.87) counts 20 members, plus another eight persons 'on the margin'; Skornicki (2006, p.6) puts the number at 16 . The number of works associated with the circle is estimated at about 40 (Charles 2011, p.12; Skorniki 2006, p.16).

${ }^{19}$ Forbonnais's biographer Fleury $(1915$, p.36) establishes that he came to Paris in 1748. Charles, Lefebvre and Théré (2011, pp.14-15) speculate that the acquaintance was originally due to earlier commercial relations between the Vincent family, merchants from Saint-Malo with business in Cadiz, and the Véron family, cloth manufacturers from Le Mans, who exported through Cadiz. When Forbonnais arrived in Paris, Gournay was 'probably one of his earliest contacts'. If so, then Gournay would have taken the ambitious younger man under his wing even before he became Intendant du commerce in 1751, a moment that sometimes is taken to signal the beginning of the cercle de Gournay.

${ }^{20}$ Daniel-Charles Trudaine (1703-1769), who took over the direction of the Bureau of Commerce in 1749 and who was Gournay's superior, was another crucial, though not unconditional, supporter of Gournay's programme from the start. Georges-Marie Butel du Mont (1725-1788) was the other early protégé of Gournay.
} 
Gournay himself, with the aid of Butel du Mont, translated Josiah Child's A new discourse of trade of $1690 .{ }^{21}$ One of Gournay's principal reasons for using this by then old work was Child's advocacy of a reduction in commercial interest rates. Where in the $17^{\text {th }}$ century Child had argued that the Dutch had beaten the English out of many branches of trade due to the latter's higher costs of mercantile borrowing, now, according to Gournay, France found itself at the same disadvantage with respect to the British. ${ }^{22}$ In his comments on the translation, he wrote for example:

Nothing in fact influences the balance of trade more than the interest on money. Because if the interest amongst us is at $5 \%$, whilst it is at 3\% amongst our neighbours, it costs them less to make the same things, and we lose in trades where the people of other nations gain. (Gournay in Tsuda 1983, p.395, my translation). ${ }^{23}$

From 1753 Forbonnais followed the same approach of using the translations of foreign works as a vehicle for reformist commentary. ${ }^{24}$ At the beginning of that year his 'free translation' of Jerónimo de Uztáriz's Theórica y práctica de Comercio $y$ de Marina ${ }^{25}$ was published and in July followed his even freer translation of Charles King's collation from The British Merchant. ${ }^{26}$ At almost the same time he was writing entries for Diderot and D'Alembert's Encyclopédie, nine of which were published in October in volume three. ${ }^{27}$ The volley of writings in that year

21 Tsuda (1983, p.vi) notes that Gournay used the fifth edition of Child's work published in Glasgow in 1751. As in earlier editions, this work had included a reprint of the much earlier 'Tract against Usury' by Thomas Culpeper the elder of 1621.

22 Tucker (1960, ch. 2) remains a good account of the controversies surrounding Child's plea for a reduction in interest rates. Flandreau et al. (2009) provide detailed comparative $18^{\text {th }}$ century data which show that Gournay was right about the higher average interest costs of commercial credit in France compared to the Dutch republic and especially Britain. It is of course a different question whether he and some of his protégées were also right to give so much weight to the higher costs of borrowing as a major cause for the lack of foreign competitiveness of French merchants and manufacturers.

${ }^{23}$ Gournay did not get permission to publish these notes and the translation was published in 1754 without them. Although it was clear that the notes were read and commented upon in private by Forbonnais, Turgot, and Mably, they were long presumed lost, until professor Tsuda, upon discovering versions in three different French archives, published them in 1983. Meyssonnier (2008) is a more recent edition of Gournay's notes which pays special attention to Forbonnais's comments on the notes.

${ }^{24}$ Clearly Forbonnais had started work before 1753 . His earliest writings on economic matters were a set of comments on Montesquieu which Fleury $(1915$, p. 161) claimed were already published in 1750, and then reprinted in 1753 in volume three of Fréron's Opuscules (which was again reprinted in 1762 - I have only been able to examine the 1753 edition). The translation of Uztáriz has a permission to print dated 8 October 1752 and on p.89, n.b, it announced the forthcoming publication of Négotiant Anglois on which he was then still working (cf. note 32 below).

25 On this translation see Guasti (2014). For the English translation by John Kippax of the same Spanish work (the second edition of 1742) and Postlethwayt's repeated use of it see van den Berg (2017b).

${ }^{26}$ On this translation see Alimento (2014b).

27 Five of these, that is, the entries 'Chambre d'assurance' (pp. 57-60), 'Change' (pp. 127-32), 'Colonie' (pp. 648-51), 'Commerce' (pp. 690-699) and 'Concurrence' (pp. 832-3) would the next year be included as chapters of the Elémens du commerce, namely chapters, 7, 8, 6, 1 and 2, respectively. Apart from a number of small changes these entries had the same wording as found in the first edition of Elémens. In addition, Forbonnais contributed 'Charte-partie' (pp. 218-20), Commandite (p.688), 'Communautê (p. 724) and 'Compagnie de Commerce' (pp. 739-43), which 
was completed by the publication in December of Forbonnais's Considérations sur les Finances d'Espagne, a work that probably started as a by-product of his translation of Uztáriz. Then in March 1754 appeared the first edition of Elémens du commerce.

All these works, but especially the last one quickly established Forbonnais's reputation as the member of the Gournay circle with the most pronounced philosophical and theoretical ambitions. Soon he would be referred to as 'the foremost [author] amongst the French to have applied the philosophical method to matters of trade'. ${ }^{28}$ It may be that this 'philosophical' leaning was inspired in part by the young author's desire to address an enlightened public and his need to impress the administration without as yet being restricted, like Gournay, by the discretion that came with holding a high position in the bureaucracy. In any case, Forbonnais was alive to the most recently available economic writings of a philosophical bent.

\subsection{Monetary views in Discours préliminaire (1753)}

This can be seen in the monetary ideas that Forbonnais developed in his Discours préliminaire $d u$ traducteur at the beginning of Le Négotiant anglois, which, although they do not yet show a clear influence of Cantillon, are relevant to our present purposes. As established by Tsuda (1993, p.xxxiv, n.6) and discussed in detail by Alimento (2014b, pp.1058-61), this lengthy discourse, which takes up about half of the first volume, shows clear traces of influence of a recent reading of Hume's economic Essays. ${ }^{29}$ The management of public credit and the British government's ability to borrow at low rates of interest forms the subject of a long digression on the pages civ to clviii of this Discours. ${ }^{30}$ It starts with the observation that the tendency for rising prices of manufactures, which in a successful trading nation like Britain is the result of increasing wealth, is offset by a low interest rate.

did not later find a place in Elémens. By the time volume 4 of the Encyclopédie was published, in October 1754, two editions of Elémens had already appeared (see Avertissement to vol.4, p.2) but the entries 'Crédit' (pp. 445-50) and 'Culture des terres' (pp. 552-66) followed the wording of chapters 10 and 3, respectively, of the first edition. Forbonnais also contributed 'Contrebande' (pp.129-131) to volume four. Only Forbonnais's final contribution, the subentry on circulation in the entry 'Especes' in volume five (pp. 959-70) followed the wording of the second edition of Elémens (cf. note 9 above). The remaining chapters 4, 5, 11 and 12 of Elémens may also originally have been written as entries for the Encyclopédie but ended up not being used in that work.

${ }^{28}$ See Grimm's Correspondance littéraire (iii, p.104; 15 October 1755): 'le premier, parmi les Français, qui ait porté, dans les matières de commerce, la méthode et la philosophie'. A more critical gloss on this same aspect of Forbonnais's writing is found half a year earlier (i, pp.318-19; March 1755): the Elémens 'would have had much greater success, I believe, if the author would have dropped the airs of a philosopher and bel esprit, which he has surely adopted too much. In these matters [this attitude] should not get too popular. Detailed accounts are needed rather than reasoned principles, and examples instead of maxims'.

${ }^{29}$ Alimento (2014b, p.1060) establishes that Forbonnais first read Hume's Essays some time between August 1752 and June 1753.

30 Significantly, Postlethwayt (1757a, pp.87-109) would a few years later insert an English translation of precisely this part (cf. n.15 above), which I will use here for quotations. 
Very much in accordance with Gournay's views, Forbonnais emphasized the very great advantage low interest rates gave to trading nations:

'Tis an evident Maxim, that whatever Nation has Money at the cheaper Interest, all other Things considered at a Par, will ruin all other Countries in Competitorship (Postlethwayt 1757a, p.87). ${ }^{31}$

After explaining this maxim with the argument that lower interest rates meant lower "opportunity costs" for traders, since 'the Merchant's Profit in Commerce is regulated by the Value of his Money placed out at Interest in the public Stocks', 32 Forbonnais proposed to explain the causes of such low interest rates from first principles (remonter à ses principes, Forbonnais 1753c, p.cvii). Here Hume's influence became apparent. First, Forbonnais pointed out that there was no straightforward connection between the money supply and the levels of interest rate in a nation and hence that with the increase of money in circulation 'the letting out of this Money does not diminish of itself [de lui-même]' (Postlethwayt 1757a, p.89; Forbonnais 1753c, p.cvii). Instead, paraphrasing Hume's 'Of Interest', it was the balance between the supply of and demand for borrowings that 'naturally' determined interest rates:

In Proportion as a greater Number of Men grow rich, and continue to enrich themselves by their Labor, the Number of Borrowers decreases, while that of the Lenders encreases. On the other Hand, the more Merchants there are, the less are their Profits, and they are accustomed to receive the less Interest for their Money. 'Tis a general Rule, that the natural low Rate of Interest denotes a large Commerce, as a natural high Interest does a small one (Postlethwayt 1757a, p.90 from Forbonnais 1753c, p.cviii-cix).

It is easy to recognize in this the 'three circumstances' that made for low interest in a state, which Hume had named in his essay 'Of Interest', namely 'a small demand for borrowing; great riches to supply that demand; and small profits arising from commerce' (Hume 1752, p.64). Forbonnais agreed that these three circumstances were 'all connected together, and proceed from the increase of industry and commerce, not of gold and silver' (ibid.). He also acknowledged that in some commercial nations this would 'of its own Accord'33 lead to a reduction in interest rates, for example in the Dutch republic where people lived very frugally and encountered few competitors in their foreign trades.

\footnotetext{
31 Translated from Forbonnais (1753c, civ): 'La maxime est évidente que entre plusieurs nations, celle qui aura l'argent à meilleur marché, toutes choses égales d'ailleurs, ruinera les autres dans la concurrence'.

${ }^{32}$ I believe it is correct to refer to Forbonnais's view of interest as constituting an "opportunity cost" for traders, especially because of his explicit use of the conditional tense: 'un négotiant commençoit par compter en dépense 1800 liv. par an sur la somme supposée pour l'intérêt que cet argent lui eût produit sur la place' (Forbonnais 1753c, p.cv; emphasis added). Postlethwayt (1757a, p.88, emphasis added) translated the last phrase as 'the Sum imagined for the Interest, which that Sum would have produced him on the Spot'. Forbonnais was hardly the first author to make such a statement, see e.g. the examples from the $17^{\text {th }}$ century in Tucker $(1960$, ch. 2$)$ but, as we will see (p.22), in later writings he much enlarged upon this idea, plus the notion that the remaining difference between trading profits and interest on government securities, consisted of risk premiums.

33 Postlethwayt (1757a, p.90); 'd'elle-même' Forbonnais (1753c, p.cix).
} 
This, however, was emphatically not what had been happing in Britain. In contrast to Hume, Forbonnais emphasized that, compared to the Dutch republic, Britain's exports were both more vulnerable to foreign competition and to increases in their prices (presumably due to a lesser 'frugality'). At the same time, the great demand for borrowing by the British state, required for fighting its many wars, threatened to increase the rate of interest on public debt. This would harm trade by attracting capitals previously employed in productive activities. 'In this critical Situation, England could not hope that the Reduction of Interest should operate of itself (d'elle-même); and a Reduction by Compulsion must necessarily hurt the Credit of the Government' (Postlethwayt 1757a, p.92 from Forbonnais 1753c, p.cxi). In response the British government, had since the 1690s therefore embarked on a series of 'well conducted' reductions in interest rates paid on its debts. Helped by a developed credit market and through careful negotiations of terms, a new kind of management of public credit had developed of which 'England seems to give the only Example' (ibid.97). ${ }^{34}$

Thus, Forbonnais was able to draw a sharp distinction between what would, abstractedly considered, happen 'of itself' and what was actually happening in particular cases. ${ }^{35}$ Rather than Hume's implicit suggestion that Britain's low interest rates were a natural consequence of it being a more advanced commercial nation with richer merchants who from being borrowers could turn lenders, what was really responsible for the reductions was a wise government management of the credit market.

Some of Hume's views of the effects of money inflows to the domestic economy in his essay 'Of Money' can also be discerned in Forbonnais Discours (1753c, cxxxvcxxxix). There was the idea that the 'actual Increase of the Mass of Metals' tended to raise prices, and that this could be due either to 'the Discovery of a Mine' or to a positive balance of trade. What should be noted, however, is that in comparison with his later views from the Elémens onwards (below p.16), Forbonnais did not yet make much of the supposed differences in effects that these two kinds of inflows would have on domestic economic activity. While 'any actual Augmentation whatsoever of Money in a State, quickens the Circulation of Commodities from one Neighbour to another', he wrote, 'it cannot be inferred, that the Quantity of this new Cash has augmented Labor of itself'. ${ }^{36}$ What Forbonnais did stress however, very much like Hume, was that the alternative expedient of

\footnotetext{
${ }^{34}$ Some aspects of Forbonnais's discussion about the management of the reductions in the credit market are a little reminiscent of Cantillon's account in the final chapter of the Essai. However, Forbonnais could have been obtained similar understanding of these operations from other British sources. In his notes to his translation of Child of 1752 Gournay had also emphasized the advantages that Britain drew from a well-developed public credit (in Tsuda 1983, pp.210-11). Of course these authors will also have studied the actual borrowing practices of the British government under the Pelhams. For a good discussion of these practices see Chamley (2011).

${ }^{35}$ As we will see below p.29, 14 years later Forbonnais would use a similar kind of argument in his critique of Quesnay's Tableau.

36 Postlethwayt (1757a, p.103) from Forbonnais (1753c, pp.cxxxvi-cxxxvii). This passage referred to the effect from an inflow of money due to the discovery of a mine, but Forbonnais did not yet draw any significantly different conclusion for the effect of inflows due to a positive balance of trade: in both cases there would be a certain increased 'briskness' in trade which would give a passing 'Motive to Industry' but 'as soon as the new Mass shall be distributed, in Proportion with the old, Commodities will be dearer, but the Circulation will not be the brisker' (ibid.)
} 
trying to speed up circulation 'by continually multiplying the Paper that passes current for Specie' would raise domestic prices and 'soon prove fatal to a Nation that holds Correspondencies with the neighbouring States' (Postlethwayt 1767a, p.104; from Forbonnais 1753c, p.cxxxviii). The next year in Elémens du commerce Forbonnais would return to these monetary themes and provide a much more detailed discussion of the sequential effects of different injections of money into circulation. By that time however, as will be argued, he is likely to have read Cantillon's Essai.

\subsection{The Essai and the Gournay circle}

Before looking at that issue, however, we briefly need to consider some of the circumstances surrounding the publication of Cantillon's work. The scholars who have studied this issue in most detail have long agreed that (a) person(s) belonging to the 'Gournay circle' will have had a hand in its publication (Higgs 1892, p.452; Tsuda 1979; Murphy 1986b). This is a purposefully imprecise statement, since there remain some outstanding questions regarding the identities of the editor, printer and publisher of the Essai. ${ }^{37}$ Regardless of the precise truth in those matters, the likely involvement of the Gournay circle does imply that a manuscript of the Essai will have been available to at least some members of this group at least some time before its publication. In fact, at least one passage in one of Gournay's memoranda leaves little doubt that he had read Cantillon's work shortly before its publication in print. ${ }^{38}$ This does not, however, settle the question from what moment at the earliest the Essai would have been available to (some of) the Gournay circle. In this respect, Morellet's well-known but much later recollection that Gournay used to encourage his protégés to read the Essai is of little use. ${ }^{39}$ My conjecture is that the Essai would not have been

37 Murphy (1986b, pp.299-308) established that the Paris publisher Pierre-André Guillyn (171581) obtained a permission tacite for its publication. Recently Sabbagh (2016, pp.24-9) has noted that this permission was actually given to Guillyn and associates and that they may have subsequently sold this permission to the publisher Marie-Jacques Barrois (1704-69). In addition, he points out the difference between these publishers and the printer responsible for producing the first edition of the Essai. This, according to Sabbagh, was the veuve Godart who was based in Amiens and who was the printer for the Amiens Academy in which Gournay played an important role. These are useful additional facts, but in my opinion this does not bring us much closer to identifying the so far elusive person who edited a manuscript of the Essai (most probably the one preserved in the municipal library of Rouen) to prepare it for print and who was responsible for numerous small alterations (see Cantillon 2015, p.15). This would not have been the widow Godart and it may be doubted whether Gournay himself would have had the inclination to undertake this job.

${ }^{38}$ As shown by Tsuda (1983, p.480), Gournay's report, the Mémoire sur le travail des gens de mainmorte, was written in 1755 , before 13 March, hence only a few months before the publication of Cantillon's work. The passage in question, which evidently relies on Essaiiii.1.4 (Cantillon 2015, p.357 [E490]), reads: 'ces dentelles qui sont que le produit du quart d'un arpent semé en lin occupe deux milles personnes' (in Tsuda 1993).

${ }^{39}$ Morellet (1821, i, p.37). In a work originally written in 1764 Morellet wrote further that 'from about 1750 the signal for this study [of political economy] amongst us was given by the edition of the excellent Essai sur le Commerce en général by Mr. Cantillon, the translations of some English works, like that of Child by the late Mr. de Gournay, and some other works written and published at the prompting of that respectable magistrate' (Morellet 1775, pp. 9-10). It is not clear from this passage whether Morellet meant to say that the Essai was edited as early as 1750 or that the 
available to them before 1753 , but it has to be acknowledged that the evidence in this regard is not conclusive. ${ }^{40}$

Another thing that is worth noting is that it is not obvious how the publication of the Essai fitted in with the reformist and literary strategies of the group. In the first place, Tsuda (1983, p.481) has a point when he observes that Gournay himself did not overtly have a strong affinity with Cantillon's rather abstract treatise, one that tended to eschew policy recommendations, noting that 'despite [evidence of his familiarity with the Essai] it does not appear that Gournay himself could accept the principal arguments of Cantillon. This is perhaps because Gournay was more a practitioner than a theorist' (my translation). ${ }^{41}$ Second, the presentation of the relevant, i.e., the first, print edition of the Essai was different from all other publications emerging from the group in that it was virtually devoid of the customary additional apparatus, like an editor's introduction, copious notes or any other form of commentary. 42 In those other works often such paratext, in which the group's reformist agenda was developed, was the principal rationale for the publications. Of course one may argue that Gournay and his group thought Cantillon's work such a perfect construction that they decided it required no further editorial exegesis. If so, this still begs the question how it suited their reformist agenda.

A good way to address this question is to examine the writings of the more theoretically minded members of the Gournay circle for traces of possible influence of Cantillon. As may already be clear from the short impression given above of the impact of Hume's writings on Forbonnais's monetary ideas, this is not a straightforward exercise. The similarities between a number of monetary views of Hume and Cantillon have often been noticed and historically they have indeed

various activities he mentions were set in train from about the beginning the decade. If he indeed meant the former, he may simply have been mistaken about the dates. Morellet was not a very early member of the group and was introduced to Gournay by his friend Turgot around 1755 (see Morellet 1821, i, p.36).

${ }^{40}$ In Cantillon (2015, pp.9-10) I argue that there is scant evidence for the view that multiple manuscripts of Cantillon's Essai circulated in French literary circles in the decades between 1734 and 1755. Instead my hypothesis is that there existed just a single complete French manuscript, which was in Mirabeau's possession from the later 1730s, from which he had made extracts for his personal studies, and which was subsequently returned to the original owner or his descendants in about 1753. Only after this it would have been passed on to Gournay, or to one of his protégées. Sabbagh (2016) correctly criticizes my imprecise statement in Cantillon (2015, p.14) that no influence of Cantillon's ideas is found in French works published prior to 1755. For clarity, I should of course have exempted the writings of authors belonging to the Gournay circle in the years 17535. Still, I cannot agree fully with what Sabbagh takes as evidence of influence of a reading of the Essai by Dangeul (see below pp.12-13, but also n.47).

41 Murphy (1986b, p.318) expressed a somewhat different view by surmising that Gournay changed his views on the beneficial effects of public credit due to his reading of the Essai. There appears to be little evidence to support this particular view.

42 The title page of the Essai of course exhibits similarities with other books associated with the Gournay circle, especially the same fictitious place of publication and publisher. However the text itself is completely devoid of editorial comments, apart from a single well-known footnote on $\mathrm{p}$. 377, which commented on Newton's presumed confusion between 'essence and form' (Cantillon 2015, p. 435). Another difference with other publications associated with the Gournay circle is that the Essai derived from an earlier manuscript that was already written in French, and hence was not a translation by a person belonging to that group. 
frequently been confused (see van den Berg 2012a and Cantillon 2015, p.36). ${ }^{43}$ Hence, if one can distinguish at all between the separate influence that the monetary views of the Scotsman or the Irishman may have had on later authors, then this often requires close attention to precise formulations. An example is the paragraph quoted above (p.9) where Forbonnais, in my view evidently, depends on Hume for the formulation of how interest rates would normally be determined between lenders and borrowers. Even though Cantillon (2015, p.320 [E435]) also stated that 'the interest of money in a state is settled by the proportionate number of Lenders and borrowers', the actual formulation of this idea is in fact quite different from what is found in Hume and in Forbonnais's Discours préliminaire. Consequently, it may be argued that those monetary views expressed in Négotiant anglois that appear similar to those we find in Cantillon, can be found with a greater degree of textual similarly in Hume's Essays or other earlier writers.

The same can possibly be said for some interesting passages in Plumard de Dangeul's Remarques sur les avantages et désavantages de la France et de la Grande-Bretagne of $1754 .{ }^{44}$ Sabbagh (2016, p.8) argues that in chapter 6 of this work Dangeul provided an account of the 'Cantillon effect', the occurrence of which he explains as a borrowing from that eponymous author. It seems more likely, however, that the relevant passages sooner owe something to Hume. In fact, Dangeul's discussion from the bottom of page 345 up to page 350 reads like a thinly-disguised paraphrasing of the Scottish philosopher's 'Of Money'. ${ }^{45}$ This does include an intriguing passage about the delayed effect of the inflow of money from foreign trade on domestic prices. Dangeul asserted:

\footnotetext{
43 The question what may explain the striking similarities between several of the monetary views of Cantillon and Hume is left to one side here. Hayek (1931) and, following him, Thornton (2007) are the foremost proponents of the view that Hume had in fact read and copiously borrowed from one of Cantillon's manuscripts. Although the precise evidence in favour of this case does not appear fully convincing (see Cantillon 2015, p.26 n.18), this does not preclude the possibility that this is precisely what happened.

44 This work was published at the end of February, meeting with immediate success in France and abroad. In April 1754 Grimm's Correspondance Littéraire noted that Dangeul's book had sold out in days and that further prints were under way. At least three reprints and an augmented edition of the French work were published in 1754 alone. An English and a Swedish translation were published in the same year. In the next two years followed Spanish, Danish, German, and Italian translations. The English translation, used here for quotation, was based on the second French edition (see Dangeul 1754b, p.v).

${ }^{45}$ My principal reason for saying this is that the order of Dangeul's argument closely followed that of Hume's 'Of Money'. This order is as follows: (1) the paragraph that starts at the bottom of page 345 makes two points that are also found in the first paragraph of 'Of Money' namely (a) that in a country considered by itself the quantity of money 'seroit indifférente' (Dangeul 1754a, p.346; 'would be a matter of indifference' [Dangeul 1754b, p.231]; cf. Hume: 'is of no consequence') and (b) that, nevertheless, the amount of money a nation can command crucially affects it ability to wage war and defend its commercial interest; (2) the next paragraphs in both texts make the point that nations that are successful in trade see gold and silver flow into the country which eventually raises prices; (3) the following paragraph in both texts states that the rise in prices is further unnecessarily increased by the circulation of 'Bank-bills, other paper-currencys of the Government, Companies \&c.' (Dangeul 1754b, p.232); (4) finally, both Hume and Dangeul then devoted attention to the notion that the effect of an injection of additional money takes time to work through the economy (cited in the main text above). Given this same structuring of the argument over several pages in the two texts, it seems scarcely possible that Dangeul did not here take his inspiration from 'On Money'.
} 
In a State well-peopled, to which commerce and manufactures are novelties, or which shall have opened to itself a new trade, the importation of gold and silver, is [i.e., takes] much a longer time, before it makes that inconvenience be felt, which arises from its abundance: because, as fast as money becomes plentiful, industry displays itself: the demands of luxury are multiplied: the number of workmen increases: new branches of foreign trade open [...]. (Dangeul 1754b, p. 233).46

Compare this with Hume (1752, p. 47):

[...] though the high price of commodities be a necessary consequence of the increase in gold and silver, yet it follows not immediately upon that increase; but some time is required before the money circulates through the whole state and makes its effect be felt on all ranks of people. [...] it is only in this interval or intermediate situation, between the acquisition of money and rise of prices, that the increasing quantity of gold and silver is favourable to industry.

Apart from Dangeul's greater emphasis on the idea that the delayed effect on prices was especially relevant to populous states where 'commerce and manufactures are novelties', there was very little here that was not found in very similar words in Hume's essay. That is not to say that we can be confident that Dangeul had not read Cantillon's Essai when he wrote his Remarques. ${ }^{47}$ Nevertheless, as far as the monetary ideas in the latter work are concerned, the same thing is true as for his cousin's Négotiant anglois: these views seem to owe more to Hume.

Before examining the changes in the formulation and presentation of Forbonnais's monetary ideas in Elémens, three things may be noted briefly about his and Dangeul's way of working when borrowing some of the monetary views of David Hume. First, they showed themselves capable of adopting these views rather quickly, perhaps within a year of their first publication. Second, they did not name the Scottish philosopher or his writings as a source. ${ }^{48}$ Third, they did not simply copy Hume's ideas but instead assimilated them in a conditional way to support

\footnotetext{
46 'Dans un Etat bien peuplé, pour qui le Commerce \& les Manufactures sont nouvelles, ou qui s'est ouvert un Commerce nouveau, l'importation de l'or \& de l'argent est bien plus de temps à faire sentir l'inconvénient qui naît de son abondance; parce que à mesure que l'argent augmente, l'industrie se développe les besoins du luxe se multiplient, le nombre des ouvriers augmente, de nouvelles voies de Commerce extérieur s'ouvrent' (Dangeul 1754a, 348-9).

${ }^{47}$ Indeed there may be some other clues in the Remarques that Dangeul hadread the Essai. Murphy (1986b, p. 315-16) points out a passage in Dangeul (1754a, p.266-9) that, amongst other things, talked about the distribution of men across 'countryside, market towns, villages and cities'. In addition, Sabbagh (2016, 7-8) highlights a passage (Dangeul 1754a, p.28-9) about the loss of working days in Catholic France due to its many religious holidays. Both of these passages are indeed reminiscent of what Cantillon had written, although neither of these ideas was perhaps so unique to him. Murphy further suggests that it was Dangeul who wrote an anonymous review of the Essai in the Journal des sçavans, but this took place after its appearance in print.

48 Forbonnais first named Hume in the chapter 'Of Luxury' in Elémens (Forbonnais 1754b, ii, p.238). Of course that does not mean that members of the Gournay circle did not want to be associated with Hume's writings. On the contrary, as Charles (2008) shows, in 1754 Le Blanc used copious comments in his translation of Hume's Political Discourses that included various references to French authors, amongst whom Forbonnais, to suggest ways in which readers should interpret and modify the views of the Scottish philosopher.
} 
their own views. Each of these points is relevant for the alleged use that Forbonnais would soon make of Cantillon's Essai.

\section{Section 3 'Circulation' in Elémens du commerce}

Elémens du commerce was first published in March 1754, about nine months after Le Négotiant anglois. As was noted, five of the chapters had already appeared in October 1753 as entries in volume 3 of the Encyclopédie, but the remaining seven chapters, including chapter ix, De la Circulation de l'Argent, followed now. Compared to the views that Forbonnais had presented in Négotiant anglois about the effects of changes in the domestic money supply and in interest rates on economic activity, a number of changes can be detected that suggest that Forbonnais had taken inspiration from Cantillon's Essai.

It should be acknowledged that this claim is not completely new. Some earlier students also noticed parallels between Forbonnais's monetary theories in Elémens and what is found in Cantillon, but they quickly rejected the notion of a literary dependency for the simple reason that the book was published one year before the Essai. ${ }^{49}$ As was argued in the previous section, however, since Forbonnais at this time belonged to Gournay's coterie it is not implausible that he would have been able to read Cantillon's Essai in manuscript around 1753. This would of course have merely extended Forbonnais's existing knowledge of the monetary thought of a range of authors, including Law, Melon, Dutot, Montesquieu and, latterly, Hume, and hence one should not exaggerate the sole influence that Cantillon may have had on him. In addition, the notion of 'influence' is of course not limited to a simple copying of ideas, but may very well extend to cases in which earlier works inspire quite distinct novel reasoning. As will be shown in section 3.2, the latter certainly applies to Forbonnais's views on 'compound circulation'.

\subsection{La circulation naturelle}

The first thing to note is that in Elémens Forbonnais cast his arguments about the effects of changes in the money supply and interest rates much more explicitly in terms of the larger conception of circulation..$^{50}$ To be sure, he had used the term

\footnotetext{
${ }^{49}$ See Harsin (1928, p.234 n.1) who called the possibility that Forbonnais may have been indebted to Cantillon 'troubling', but rejected it since it was 'unlikely' that Forbonnais might have had access to the manuscript of the Essai that Mirabeau had had in his possession. Morrisson and Goffin (1967, p.24) repeated the same view. These commentators were apparently not aware of Forbonnais's involvement with the Gournay circle and of the latter with the publication of the Essai. Before Harsin, Monroe (1923, pp.185-6) had unwittingly pointed out the same parallels. Not realizing that the passages he was reading in Postlethwayt (1757a, p.335-40) about the stimulating effects of an additional monetary influx on the domestic economy, were in fact faithful translations from Elémens, Monroe commented that this 'was probably inspired by some phrases of Cantillon's'. See also below n.74.

50 Hume, it should be remembered, had presented his economic views in a discrete set of essays that showed some coherence, but did not constitute a systematic economic treatise and, importantly in the present context, did not present the concept of circulation as fundamental to such a systematic account. Cantillon's Essai did. Inter alia note that the title of Elémens chapter ix is identical to that of chapter 3, part 2 of Cantilon's Essai and that the somewhat altered title of essentially the same text in the Encyclopédie section, De la circulation, du surhaussement \& de
} 
'circulation' with some frequency in Négotiant anglois, and even presented a somewhat elaborate version of the blood-money metaphor, but this was nothing too remarkable given the similar use of language by for example Melon. ${ }^{51}$ In chapter 9 Forbonnais started his discussion with what he called a préambule (1754b, ii, 137) about exchange ratios between gold and silver coins, ${ }^{52}$ before settling upon his 'principal object, which is the circulation of money, and I will not speak of the increase and decrease of monies until the place where the principles of circulation require this' (Forbonnais 1754b, ii.137). The most striking feature perhaps of Forbonnais's discussion was his distinction between 'two sorts of circulations of money: the one natural [naturelle], the other compound [composée]' (Anonymous 1767; from Forbonnais 1754b, ii.139). The 'natural' circulation of money he imagined to be a circuit where money only functioned as medium of exchange and no lending of money occurred (ibid. 1754b, ii.145). In this circulation money was simply a 'sign' that facilitated the 'exchange of commodities for commodities'. ${ }^{3}$ To nations that had no foreign trade the absolute amount of money in circulation did not matter: if there were 100 pounds in circulation in one nation and 200 pounds in another, then 'what will be worth one ounce in the one, will cost two ounces in the other. [But] the inhabitants of both these countries will be equally happy in regard to the use they can make of their

l'abaissement des espèces, is in turn reminiscent of that of Essai chapter 6, part 2. See Cantillon (2015, p.262 [E338]).

51 'If 'tis a true Saying, that Money performs the same Functions in a Body politic, as the Blood does in the human Body, the Superabundance of the one, must be as dangerous as that of the other. The Science of Physic, teaches to maintain an Equilibrium among the Fluids; and the Skill of the Politician consists in establishing a Balance between the different Employments of the People. [...] The Sea Ports are the Arteries of the Body politic, the capital City is its Heart, and the Plenty of Coin can never hurt it, if its Motions are regular and quick in the Circulation of beneficial Commerce' (Postlethwayt 1757a, pp.105-6 from Forbonnais 1753c, pp.cxli-cxlii). This passage appears inspired by Melon (1736, pp.353-4) who had confirmed that the blood-money metaphor was by then a conventional trope: 'the Body politic has often been compared to the human body: blood animates the one, money animates the other [etc.]'. Before Melon the metaphor figured, for example, in Vauban (1691, p.561) and Law $(1714$, p.605) and in Forbonnais's generation it was used by, amongst others, Goudar (1756, 3, p.176) Turgot (1770, p.575), and Helvétius (1773, 2, pp. 104-5). In view of this common usage, it is perhaps remarkable that Cantillon nowhere drew a comparison between blood and money circulation, preferring instead hydrological analogies. In Quesnay's case too it should perhaps be said that, despite the emphasis given by various commentators to his medical background and the possible importance of this for his economic conceptions (see e.g. Sutter 1958, Foley 1973, Groenewegen 2001), it is actually surprising how little use he made of the analogy in his economic writings. It is true that Mirabeau in some places noted a similarity between the circulations of money and blood (see Mirabeau 1760, p.54; 1763, p.5, p.24) and that his co-author Quesnay would probably have objected if he had been against the use of the metaphor. But one should be careful not to draw far-reaching conclusions based on the usage of this then conventional metaphorical language for the medicalinspiration of specific novel economic conceptions.

${ }^{52}$ Like other earlier authors, Cantillon had dealt with this topic too, most notably in Essaich.4, part 3. In my opinion there are no strong indications that Forbonnais would have relied on that account, perhaps with the exception of the fact that when the latter considered the effects of change in the proportion units of gold (a) to silver (b) from $a=15 b$ to $a=16 b$ (Forbonnais 1754b, ii, 124-5) he used the same figures as the former (see Cantillon 2015, p.428, [E584]).

53 'un échange des denrées contre les denrées' (1754b, ii.138). For a similar point see Forbonnais (1753c, i, cxxxv). 
commodities amongst themselves' (Anonymous 1767, p.169; from Forbonnais 1754 b, ii.140). ${ }^{54}$

Striking similarities with Cantillon's views started appearing from the point where Forbonnais considered the effects of the introduction of 'a new mass of money' into domestic circulation. This increase, according to him, could occur in two main ways 'one is, by the working of mines; the other by foreign trade' (Anonymous 1767, p.173). ${ }^{55}$ Like Cantillon, Forbonnais, proceeded to consider the different effects of each kind of injection of cash in turn, starting with the effects of an increased exploitation of mines. The two authors introduced this case in the following ways ${ }^{56}$ :

The money which comes from the possession of mines may, through several causes, not be put into the trade of the nation. It is in the hands
If the increase of [-] money comes from [rich] Mines of gold or silver in the State the Owner of these Mines, the Adventurers, the Smelters, Refiners, [mine workers of all kinds] will increase their expenses in proportion to their

\footnotetext{
${ }^{54}$ Forbonnais (1753c, i, p.cxxxv) had already made the same point in a less elaborate way and, as was suggested above, had probably been inspired by Hume. However, I believe there is a small mystery with regards to the particular formulation we find in Elémens (Forbonnais 1754b, ii.140): it is rather closer to the wording found in Postlethwayt's Dictionary entry 'Barter' (see Cantillon 2015, p.204 [D250]). For a discussion of the relevant passage see van den Berg (2012, pp.19-21). As noted above n.13, it is at least possible that Forbonnais knew Postlethwayt's entry. But perhaps the former conceived of this formulation himself and the similarities with the passage in Postlethwayt's entry might be a coincidence.

55 From Forbonnais (1754b, ii.153-4). Note that this time a third cause of the increase in prices, that is, 'by continually multiplying the Paper that passes current for Specie' (see above p.9) was not immediately considered. This case was relegated to the discussion of credit in chapter 10 of Elémens. The reason for this may be that, unlike Hume, Cantillon avoided actually calling circulating paper instruments money. To the latter this kind of medium was an alternative rather than an addition to (metallic) money. For a discussion of this difference between Hume and Cantillon see Le Maux (2014, p.961).

56 In the French originals these passages read as follows (for the passage in Cantillon, on the right, the wording of the Rouen manuscript, rather than the printed text, is given, since on my hypothesis of Forbonnais's early knowledge of the Essai, the former arguably offers the proper comparison):
}

L'argent qui vient de la possession des mines peut n'être pas mis dans le commerce de l'état par diverses causes. Il est entre les mains d'un petit nombre d'hommes; ainsi quand même ils useroient de l'augmentation de leur faculté de dépenser, la concurrence de l'argent ne sera accrue qu'en faveur d'un petit nombre des denrées. La consommation des choses les plus nécessaires à la vie n'augmente pas avec la richesse d'un homme; ainsi la circulation de ce nouvel argent commencera par les denrées les moins utiles; \& passera lentement aux autres qui le sont davantage (Forbonnais 1754b, ii, 154).
Si l'augmentation de l'argent vient de riches Mines d'or ou d'argent dans l'Etat, le Propriétaire de ces Mines, les Entrepreneurs, les Fondeurs, Affineurs, Mineurs travailleurs de toutes especes, ne manqueront pas d'augmenter leurs dépenses à proportion de leurs gains. Ils consommeront dans leurs ménages plus de viande et plus de vin ou de bierre, qu'ils ne faisoient, ils s'accoutumeront à porter de meilleurs habits de plus beau linge, et avoir des Maisons \& d'autres commodités d'une plus grande propreté et convenance et par conséquent donneront de l'emploi à plusieurs Artisans qui n'avoient pas auparavant tant d'ouvrages, \& qui par la même raison augmenteront un peu leur dépense à leur Tour; toute cette augmentation de dépense en viande, vin, laine \&c. diminura nécessairement la part des autres habitans de l'Etat qui ne se sentent pas d'abord des richesses des Mines en question. Les altercations du Marché, ou la demande pour le vin, la laine, \&c. est plus forte qu'à l'ordinaire, ne manquera pas d'en hausser les prix (Cantillon 2015, p.266). 
of but a small number of men; therefore even if these should use the increase of their ability to spend, the competition of money will be increased only in favour of a small number of commodities. The consumption of the things most necessary to life does not increase with the riches of man; therefore the circulation of this new money will begin with the least useful commodities, and pass slowly from thence to those which are of greater use.

(Anonymous 1767, pp.173-4) gains. They will consume in their households more Meat, Wine, or Beer than before, will accustom themselves to wear better cloaths, finer linen, [and have Houses and other commodities that are neater and more befitting]. They will consequently give employment to several Mechanicks who had not so much to do before and who for the same reason will increase their expenses [at their turn]: all this increase of expense in Meat, Wine, Wool, etc. diminishes of necessity the share of the other inhabitants of the State [who are not at first touched by] the wealth of the Mines in question. The altercations of the Market, or the demand for Meat, Wine, Wool, etc. being more intense than usual, will not fail to raise their prices.

(Cantillon 2015, p.267; Higgs translation apart from manuscript variations in brackets)

Despite obvious differences in wording, typical of Forbonnais's style of 'freely' adopting ideas of earlier authors, ${ }^{57}$ the structure of the argument developed in the two passages is strikingly similar: (1) the additional money will first be in the hands of but a small number of men' (Forbonnais), that is, those most directly concerned with the mining operation, 'the Owner, Adventurers, Smelters, Refiners (Cantillon); (2) they tend to spend their increased incomes on 'the least useful commodities' (Forbonnais), that is, 'better cloaths, finer linen, and other choicer commodities' (Cantillon); (3) only 'slowly' will 'the circulation of new money' pass to commodities of 'greater use' (Forbonnais), or to 'other inhabitants of the State who are not at first touched by the [additional] wealth' (Cantillon).

Forbonnais next argued that more widespread beneficial effects are to be expected from an increase of money in circulation that is due to a positive balance of foreign trade. As opposed to the increased exploitation of mines, which at first benefits only a very small group of people and a limited range of goods, 'foreign trade comprehends every sort of commodity, and every class of people. We will therefore lay down as a maxim, that circulation will increase more surely and more speedily in a state by the advantageous balance of its trade with foreigners, than by the possession of mines' (Anonymous 1767, p.174). This distinction also finds support in Cantillon's view that it is 'above all by a regular and annual balance of trade [...] that a State grows most substantially' (Cantillon 2015, p. 297, cf. p.273 [E355]). ${ }^{58}$ Despite the more diffuse entry of additional money into the

57 Cantillon's description appears more detailed and Forbonnais follows the structure of the argument more than the exact wording. Still it may be worth noting two similarities in wording that are obscured when one only looks at the printed version of the Essai (see Cantillon 2015, p.267, V348 a and f). First, where the print version of the Essai has 'I'argent effectif at the start of the passage, the Rouen manuscript, like Forbonnais, simply has 'I'argent'. Second, the print version suppressed the phrase 'à leur Tour', and Forbonnais used this same phrase in a striking nearby passage to emphasise the sequential nature of the effect of a monetary stimulus (see note 60 below).

58 It may be perhaps be contested whether the expression 'le plus solidement' (Cantillon 2015, p. 296) has the same meaning as 'plus sûrement \& plus promptement' (Forbonnais 1754, ii, 156), but the views are surely very similar. Cantillon associated the influx of money from mining with the historical experience of Spain and Portugal, where this new wealth had given rise to a tendency to buy foreign goods, rather than develop domestic industry (Cantillon 2015, p.272, [E353, E354]). Cantillon, it must be noted, was only one of many authors since Jean Bodin, who told this 
nation by means of a positive balance of trade, Forbonnais assumed the same sequential process whereby first expenditures on some commodities, will rise, before prices increase:

[a]ll augmentation of the mass of money [due to a positive balance of trade], begins with multiplying its function of sign, before it augments its bulk of sign: that is to say, that the new money, before it raises the price of commodities, will attract into trade a greater number of them [i.e., commodities] than there were before. But at length this bulk of the sign will be augmented in compound ratio of the old and new masses, whether of commodities, or of their signs. In the mean time, it is clear that this new mass of money will necessarily have awakened industry in its first passage (à son premier passage) (Anonymous 1767, p.174).

Forbonnais offered a strikingly detailed account of the sequential process set in train by the inflow of money from abroad. He portrayed the 'first passage' as a process whereby an increased amount of money entering domestic circulation 'competes' for one particular commodity. Rather than immediately raising its price, this would attract an additional market supply of that commodity, either by domestic or foreign traders who sought to 'profit by the demand for it' (ibid.174; Forbonnais 1754b, ii, 157: ' profiter de la faveur qu'elle a acquise'). ${ }^{59}$ Subsequently the additional money incomes earned by the sellers of the commodity were diffused throughout the economy:

The workmen employed in this [first] commodity finding that they have gained an augmentation of signs, will therewith establish a new rivalship in favour of the commodities they shall want to consume. By a happy concatenation [un enchaînement heureux], the signs employed in the new consumption will in their turns have the same influence with other men. The benefit will be repeated till it has gone through all the classes of people useful to the state, that is to say of people employed (Anonymous 1767, p.175).60

cautionary tale and Forbonnais wrote in various places about the same historical experience. See e.g. his comments on Montesquieu, book 21, ch.18 (Forbonnais 1753a, pp. 124-127) and his account of the poor state of the Spanish economy in Considerations sur les Finances d'Espagne. Hume, of course, also distinguished between the increase in the supply of money due to the mining of precious metals and its increase due to a positive balance of trade, but he did not elaborate much on this distinction. Nevertheless, Wennerlind (2005) argues that the distinction is crucial for understanding Hume's position.

${ }^{59}$ Cf. Cantillon (2015, p. 275): 'If an annual and continuous balance has brought about in a State a considerable increase of money it will not fail to increase consumption, [and] to raise the price of everything [...] unless additional produce is drawn from abroad proportionable to the increased consumption'.

${ }^{60}$ 'Les ouvriers occupés par le travail de cette denrée se trouvant une augmentation de signe, établiront avec eux une nouvelle concurrence en faveur des denrées qu'ils voudront consommer. Par un enchaînement heureux, les signes employés aux nouvelles consommations auront à leur tour la même influence chez d'autres citoyens. Le bénéfice se repétera jusques à ce qu'il ait parcouru toutes les classes d'hommes utiles à l'état, c'est-à-dire occupés' (Forbonnais 1754b, ii, 158-9). Even if Forbonnais derived inspiration from Cantillon about the gradual spread of wealth throughout the nation, there was certainly a difference in emphasis. Forbonnais's distinction between 'least useful' commodities and ones of 'greater use' is related to his views about the relative importance of different social orders and economic activities. He asserted that the additional spending is only really beneficial to the nation if it eventually reaches the 'class of men occupied in the production of useful and necessary commodities, [it] is that which ought to be 
The main idea of this 'happy concatenation' rested on the assumption, also found in Cantillon that 'in general an increase in actual money causes in a State [first] a corresponding increase of consumption which [subsequently] gradually brings about increased prices'. ${ }^{61}$ While such a view can also be found in Hume's 'On Money', what is striking about Forbonnais's account is a peculiar notion that the effect is propagated throughout the economy by a sequence of increased 'rivalship' (concurrence) of money for commodities. ${ }^{62}$

What Forbonnais seems to have had in mind was that at any specific moment potential buyers offer a definite amount of money for the readily available quantity of each particular traded good. Whenever the amount of money available for the purchase of a commodity increased it would 'establish a new rivalship in favour of the commodities'. This did not necessarily result in increased prices of commodities: if the quantities of the commodities offered for sale could also be increased then '[t]his new rivalship [between suppliers] of the favoured commodity re-establishes a kind of equilibrium between it and money; that is to say, that the increase of the signs destined to be exchanged for this commodity [destinés à échanger cette denrée] is diffused amongst a greater number of people or of commodities: the function of the sign is multiplied' (Anonymous 1767, p.175). This peculiar account is reminiscent of the descriptions Cantillon had given in Essai part 3, chapter 2 of the determination of market prices. Indeed, in this context Forbonnais's unusual employment of the term concurrence is similar to Cantillon's equally idiosyncratic use of the word altercations. ${ }^{63}$

Clearly, Forbonnais also considered the presumed negative effects of eventual increases in domestic prices for the foreign competitiveness of domestic producers. In accordance with what he could have read in both Hume and Cantillon, Forbonnais acknowledged that

strengthened most, because it supports all the others' (Anonymous 1767, p.174). Perhaps connected to this are Forbonnais's views on social justice emphasized by Meyssonnier (1989).

61 'J'estime en général qu'une augmentation d'argent effectif cause dans un Etat une augmentation proportionnée de consommation, qui produit par degré l'augmentation des prix' (Cantillon 2015, p.266). The actual term 'Cantillon Effect' appears to have been introduced only by Blaug (1962, p.21) to highlight the notion of a 'differential effect of a cash injection, as governed by the nature of the injection', but of course earlier historians of economics had already acknowledged its significance. See e.g. the discussion of Rist (1938, pp.286-7).

62 The word concurrence in this context clearly caused some trouble to the English translator(s). For example, the statement in Forbonnais $(1754 \mathrm{~b}, \mathrm{ii}, 142)$ that 'l'effet de cette circulation naturelle, est d'établir entre l'argent \& les denrées une concurrence parfaite' was translated in Postlethwayt (1757a, p.335) with 'the Effect of this natural Circulation is to establish between Money and Commodities a perfect Rivalship'. In the alternative translation the last three words were replaced with 'a perfect competition' (Anonymous 1767, p.170).

${ }^{63}$ See Cantillon (2015, p. 203, comment i) for his frequent use of 'altercations'. Curiously, whilst the Essai does not have the term 'equilibrium', used by Forbonnais in this context to indicate a balance in discrete market places between amounts of money and quantities of individual types of commodities, one does find a very similar usage of that word in the Postlethwayt version of Cantillon's chapter (ibid. p. 196 [D241] and p. 202 [D248]). This version was included in the entry 'Barter' of Postlethwayt's Dictionary, which was included in an issue first published by the third week of March 1752. Cf. n.13 above. 
[i]t would seem then, that foreign trade, the object of which is to attract continually new money, would work its own destruction in proportion to the progress it makes of this kind, and therefore that the state would deprive itself of the benefit which arises therefrom to circulation (Anonymous 1767, p.179). ${ }^{64}$

Forbonnais was at pains to argue that this was a distant prospect that would only be realised if society would reach a stage of development at which it 'would be invested with all the strength of which it is susceptible' (ibid.). ${ }^{65}$ Before that situation would come about, if ever, many citizens became richer and they would 'cause a part of the [gold and silver money] to be wrought into plate; or they convert it into precious stones, or into commodities of such known scarcity, as to everywhere held equivalent to a large bulk of metals' (ibid. 180; from Forbonnais $1754 \mathrm{~b}, \mathrm{ii}, 178)$. As a result, only part of the additional wealth acquired from abroad would be brought into circulation and hence the presumed tendency for prices to rise would only be very gradual. To an extent this echoed Cantillon's views that before a State 'arrived at the highest point of wealth' [...] 'many wealthy individuals would spring up who [...] will buy Pictures and Gems from the Foreigner [and] Silks and rare objects'. Also to prevent rising prices, the government should 'withdraw money, keep it for emergencies, and try to retard its circulation' (Cantillon 2015, p. 299). ${ }^{66}$ However, where Cantillon only thought this at most a temporary fix, since the eventual decline of states grown rich from commerce was 'according to the natural course of humanity' (ibid.), Forbonnais felt that this downturn was perhaps not inevitable at all. In addition, he associated the hoarding that citizens of rich nations were capable of, with money lending and the establishment of public credit. These, however, were phenomena that he classed under 'compound circulation'.

\subsection{La circulation composée}

The ideas in Elémens about the determination of interest rates and the effects of the cost of borrowing money on productive activities had also evolved from Forbonnais's previous thoughts on these issues in Négotiant anglois. In terms of

\footnotetext{
64 'Il paroît donc que le commerce étranger, dont l'objet est d'attirer continuellement de nouvel argent, travailleroit à sa propre destruction, en raison des progrès qu'il fait dans ce genre, \& dèslors que l'état se priveroit du bénéfice qui en revient à la circulation' (Forbonnais 1754b, ii, 172). 65 Forbonnais (1754b, ii, 174) 'seroit revêtue de toutes les forces dont elle est susceptible'. Sonenscher (2007, p.184) and Hont (2008, p.273) each give their own interpretations of Forbonnais's more optimistic response to Hume in what they see as part of the 'rich country-poor country' debate. While both also discuss Cantillon in the context of their wide-ranging theses about these debates, neither perceives a connection between the writings of that author and those of Forbonnais.

66 Blaug (1962, pp.21-2) emphasized the difference between Hume and Cantillon about the possibility of taking precious metals out of circulation. Forbonnais could be said to side with Cantillon on this point. A minor point is that the manuscript version of the Essai has the word resserrer instead of the word retirer (Cantillon 2015, p.299, V401c). As will be seen presently, Forbonnais gave the former word much import in his views about interest rates. Also, Cantillon's view (2015, p.299 [E402]) that 'it is not easy to discover the time opportune' for adopting policies to reduce money circulation appears to be echoed by Forbonnais's opinion that it would be 'impossible to determine in what length of time the bulk of signs may increase in a state to such a degree as to interrupt its foreign trade' (Anonymous 1767, p.180; Forbonnais 1754b, ii, 176).
} 
their presentation the most striking difference was that now the lending of money was imagined as an additional circuit; besides the 'natural' circulation of money, Forbonnais asserted, one could also study the 'compound' circulation of money, that is where money was used not only for facilitating the exchange of commodities but also for lending. The very distinction between these 'two sorts of circulations of money' (Anonymous 1767, p.169) seemed to echo Cantillon's observation that 'though money passes for a pledge in exchange it does not multiply itself or beget an interest in simple circulation'. 67 This begged the question what was the "not-so-simple" circulation in which money "begets an interest'?

Forbonnais provided an intriguing answer. The superior security of precious metals compared to other commodities and the inequality of needs between men meant that 'some proprietors of money hoard up what they have of it beyond the amount of their wants' (Anonymous 1767, p.170). 68 The more money was hoarded up, the less was available as means of payment, and this, Forbonnais argued, had disastrous effects on trade. The practice of the borrowing of money then should be understood as the route whereby hoarded money was returned to circulation:

To bring this [locked up] money back into trade, they who are in great want of it will offer its proprietors a profit to part with it for a time. This profit will be proportioned to the want of the borrower, to the advantage it may be of to him, and to the risk run by the lender (ibid. 171).69

There are some aspects of this explanation of interest that are reminiscent of Cantillon and others that are quite different. Cantillon had similarly written that because lending involves the risk of losses 'needy men must in the beginning have tempted Lenders by the bait of profit. And this profit must have been proportionate to the needs of the Borrowers and the fear and avarice of the Lenders'. ${ }^{70}$ But in the Essai the availability of money for loan was at most only

\footnotetext{
${ }^{67}$ Whilst in the Elémens Forbonnais uses the adjective 'natural' where Cantillon used 'simple', in his later Principes he adopted the term 'simple circulation' to distinguish it from 'compound circulation'. By that time however further changes in his conception of circulation had occurred (below p.26).

68 'quelques propriètaires de l'argent fassent des amas de la quantité superflue à leurs besoins' (Forbonnais 1754b, ii.144). The reasons Forbonnais mentioned for the greater suitability of precious metals for hoarding were quite conventional; other commodities were "liable to greater inequality in their goodness', 'may be destroyed more easily than metals', precious metals 'may be hid in case of invasion by an enemy, or of troubles at home' and 'may be more easily conveyed into another country' (Anonymous 1767, 170).

69 'Pour rappeller cet argent [resserré] dans le commerce, ceux qui en auront un besoin pressant, offriront un profit à ses propriétaires pour s'en désaisir pendant quelque tems. Ce profit sera en raison du besoin de l'emprunteur, du bénéfice que peut lui procurer cet argent, du risque couru par le prêteur' (Forbonnais 1754b, ii.145-6).

70 'les Hommes nécessiteux doivent avoir dans les commencemens tenté les Prêteurs par l'appas d'un profit; et ce profit doit avoir été proportionné aux nécessités des Emprenteurs et la crainte et à l'avarice des Prêteurs'. Note the similarities in formulation with the passage from Elémens quoted in the previous footnote: both first mention 'needy' borrowers who have to tempt lenders with a 'profit'; both then state that the profit will be 'proportionate' to the need of the borrower and the fear of the lender. In fact, both authors refer to this account as the original emergence of the practice of interest payments: Cantillon $(2015,322)$ : 'Voilà ce me semble la premiere source
} 
vaguely associated with prior hoarding of money. ${ }^{71}$ By contrast, Forbonnais made much more of the idea of interest as a payment to hoarders to give up 'for a time' the security of the possession of money, asserting that hoarding was essentially related to 'mistrust' (défiance). Whenever the nation's commerce and prosperity was threatened the owners of money would be scared into hoarding it and a higher premium would have to be paid to tempt them to lend it. ${ }^{72}$

This was quite a novel theory. Negative assessments of the practice of hoarding are frequently encountered in the $18^{\text {th }}$ century. ${ }^{73}$ But they were not normally turned into an explanation of why interest is paid. Joseph Schumpeter, not realizing that he was actually reading Forbonnais, mused about (the English translation of)

a passage that interprets interest as a payment to hoarders by those who stand in need of it, i.e. as a payment necessary in order to overcome people's reluctance to part with cash. This reads like a clumsy version of Lord Keynes's own-rate theory of interest (Schumpeter 1954, p.372 n.15). ${ }^{74}$

To what extent Forbonnais's theory of interest rates in Elémens did indeed anticipate Keynes's ideas about liquidity preference is a question that is fraught with difficulties. But if there is a very general correspondence it is that both men sought to avoid the explanation of interest rates as, what Adam Smith (1776, i.vi.50) called, simply a 'derivative revenue', that is, as ultimately being ruled by profit rates. ${ }^{75}$ If that would be the case, high (low) interest rates could not be a

de l'intérêt'; Forbonnais (1754b, ii, 147): 'Telle a été, ce me semble, l'origine de l'usure ou de l'intérêt de l'argent'. It seems hard to imagine that this set of similarities of expression could occur without Forbonnais having read the Essai.

${ }^{71}$ Cantillon (2015, p.248) pays some attention to hoarding, but only in the context of his estimation of the proportion between money in circulation and total incomes. In the chapter on interest rates, on the other hand, he is extremely vague about the identity of lenders and the origins of their massed wealth, merely referring to 'anybody who is willing to lend money' (quiconque voudra prêter de l'argent). For a further discussion see van den Berg (2014, p.630).

72 See Forbonnais (1754b, ii, 147-8) consequences 1, 2, 6, 8.

${ }^{73}$ See Meek (1962, p.319-20) and Johnson (1966, p.626) who note that Quesnay shared his disapproval of the hoarding of money with an array of contemporary and earlier French authors. Of course this was true for British writers too (see e.g. Viner 1937, pp.45-8). However, there was no agreement amongst these authors about the importance of this phenomenon and perhaps none, apart from Forbonnais, used it as an explanation for the existence of interest. For an alternative interpretation of originality of Forbonnais's analysis of interest see Duflos de Saint-Amand (2011). ${ }^{74}$ Schumpeter was here referring to Postlethwayt (1757a, pp.336-7). Perhaps he was first alerted to the passage by a reading of Monroe (1923, pp.185-6) or Viner (1937, pp.47-8). The former had already flagged up to his readers as being 'quite unique', the theory of "Composite Circulation" according to which '[i]n order to bring the hoarded money back into trade, people in great need will offer to pay for the use of it, and thus arises interest as part of the expenses of every undertaking'. Viner, in turn, called 'curious' the argument of 'Postlethwayt' that 'lending of money at interest involved hoarding'. Neither Monroe, Viner, nor Schumpeter realized that Postlethwayt had plagiarized the passage in question from Forbonnais and this may have prevented them from exploring it further. In addition, the former two historians wrote before Keynes developed his views on liquidity preference in the General Theory, so they could not have made the association that Schumpeter made.

75 This could well be the reason that Forbonnais ignored Cantillon's qualification that although 'the needs of the borrowers and the fear of avarice of the lenders' appeared to be merely 'the origin of interest. But [in modern times] its constant usage in States seems based upon the profits which the 
persistent reason for economic decline (revival) and this would undermine his advocacy of a careful management of interest rates by the state.

Reprising his views in Négotiant anglois of the destructive effects of high interest rates on economic activity (above n.32), Forbonnais again argued that interest payments should be considered as "opportunity costs" to farmers, manufacturers, and merchants:

whenever it shall be easy to make a profit by, or to receive an interest for, the loan of one's money, it is evident that every man who shall incline to employ his in any undertaking whatever, will begin with reckoning amongst the charges of the undertaking what his money would have brought him in if he had lent it. [...] there is no branch of commerce to which the reduction of interest does not give motion. Every soil is fit for some production or other: but if the sale of its products does not yield so much as the interest of the money employed in the cultivation, that cultivation will be neglected or abandoned [...]. The same reasoning should be applied to the establishment of manufactures, to navigation, fisheries, the settling of colonies. The lower the interest of the advances which these undertakings require is, the more they are deemed profitable (Anonymous 1767, p.171 and p.176; emphasis added). ${ }^{76}$

There appear to be some striking similarities between these passages and what Turgot would write a decade later in sections 89 and 90 of his famous Réflexions about the interest rate as the arbiter of profitable employments of money advances. However, one difference was that Forbonnais insisted that interest rates did notautomatically move with the rates of profit in the various productive activities. ${ }^{77}$ Another crucial difference with Turgot was that Forbonnais understood by 'supply' the availability of money hoards rather than a much wider category of accumulated capitals and, on the 'demand side', emphasised the great influence of borrowing by governments. ${ }^{78}$

His views about hoarding dovetailed with his views about public credit. On a national level plenty of money reserves amongst rich citizens constituted a great

undertakers can make out of it' (Cantillon 2015, p.323). This appeared to be a hint at quite a different kind of explanation of interest, more similar to that of 'classical' political economists. However, one should be careful not to read too much into it, since as Aspromourgos (1989, pp.3701) pointed out, the causation from profit to interest is ambiguous in a number of other places in the Essai.

${ }^{76}$ 'Iorsqu'il sera facile de retirer un profit ou un intérêt du prêt de son argent, il est évident que tout homme qui voudra employer le sien à une entreprise quelconque, commencera par compter parmi les frais de l'entreprise ce que son argent lui eût produit en le prêtant' [...] 'il n'est aucune de ses branches à laquelle la réduction des intérêts ne donne du mouvement. Toute terre est propre à quelqu'espece de production: mais si la vente de ces productions ne rapporte pas autant que l'intérêt de l'argent employé à la culture, cette culture est négligée ou abandonnée'. [...] 'Le même raisonnement doit être employé pour l'établissement des manufactures, pour la navigation, la pêche, le défrichement des colonies. Moins l'intérêt des avances qu'exigent ces entreprises est haut, plus elles sont réputées lucratives' (Forbonnais 1754b, ii.146-7 and 161-2). The first passage was in fact added only from the second edition onwards, but since the idea expressed in it was almost identical to what Forbonnais had written in Négotiant Anglois (see above n.32), this seems to have little significance.

${ }^{77}$ This view was even more fully expressed in volume 6 of Forbonnais's massive historical study of 1758, especially pp. 55-75.

78 The differences between the theories of capital and interest of Forbonnais and Turgot are discussed in more detail in van den Berg (2019). 
source of power over other states. ${ }^{79}$ Public borrowing allowed the state to maintain its military strength and to defend its commercial and colonial interests (see Forbonnais 1754b, ii, 170). This would again prevent interruptions to trade and guarantee a peaceful state of affairs required to nurture the confidence amongst rich people to lend their money voluntarily at lower rates. And such reductions would in turn animate all kind of economic activity by allowing producers to operate at lower rates of profit. A state borrowing from its own citizens also was not at the mercy of foreign creditors who always had 'an infallible means of throwing a new disorder into the circulation of the state which owes, by suddenly withdrawing [their] capitals' (Anonymous 1767, p.181). ${ }^{80}$ Thus, although interest was an 'unnatural' phenomenon, the 'compound circulation' of money and its management were necessaryevils in a world of unharmonious strife between commercial nations.

\section{Section 4 Diverging Conceptions of Circulation}

Historians have, on the whole, neglected what Forbonnais wrote about circulation in publications that were nevertheless very well known in their time. This can be explained at least in part by the fact that the analysis of circular flow in France in this period came to be associated with François Quesnay and his attentiongrabbing Tableaux économiques. In October 1756, less than a year after Forbonnais's final contribution to the Encyclopédie, the sub-entry on 'Circulation', Quesnay made his debut as an economic author with his entry 'Fermiers' in the next volume of that same serial publication. By the following summer Quesnay had read Cantillon's Essai, as is clear from Mirabeau's famous account of his 'interview' at Versailles and from an acknowledgment in a footnote in his next entry, 'Grains', in volume 7 of the Encyclopédie, (November 1757). ${ }^{81}$ The first Tableaux followed again a year later.

\footnotetext{
79 'the people who possess most [money hoards], are masters of those who know not how to reduce it to its true value; [...] It is of importance to deprive one's rivals of the means of becoming powerful, because that is gaining relative strength' (Anonymous 1767, p.180; Forbonnais 1754b, ii, p.176). Cf. Cantillon (2015, p.163): 'Gold and Silver are the true reserve Stock [Corps de réserve] of a State, and the larger or smaller actual quantity of this Stock necessarily determines the comparative greatness of Kingdoms and States'.

${ }^{80}$ From Forbonnais (1754b, ii, p.181). For similar reflections see Cantillon (2015, p.304). Postlethwayt (1757a, p. 358) added a rare note of his own to this view of Forbonnais with a reflection inspired by the fears of French continental conquest at the beginning of the seven years' war: 'Does it not follow, that the more we increase our Public Debts, the more we put ourselves in the Power of Foreigners to ruin us of a sudden? If France possess Holland, may they not oblige the Dutch to draw all their Money out of our Funds?'

81 To English readers this 'interview' was made famous by Ronald Meek who started his influential The Economics of Physiocracy with this historical encounter (see Meek 1962, pp. 15-18). The sole source for this first meeting is a letter Mirabeau wrote to Rousseau ten years after the event. In the letter Mirabeau is in proselytizing mode, portraying the meeting as a 'conversion' from his earlier mistaken adherence to Cantillon's view's to the true doctrines of Quesnay. Meek was right to point out that Mirabeau is likely to have 'exaggerated the extent to which this interview changed his fundamental ideas'. In fact Quesnay may have sought out Mirabeau not only for the fame L'Ami des hommes had recently brought the latter, but also because he recognized the frequent borrowings from Cantillon's Essai in that work. For Quesnay's reference to Cantillon see Quesnay (2005, p.185 n.34).
} 
As was already noted (above n.7), the extent to which the zigzags were inspired by Cantillon's descriptions of circulation has been discussed frequently. In Meek's judgment 'Cantillon's inspired hints about the circulation of money and goods in a predominantly agricultural kingdom developed under their own momentum in Quesnay's mind once he had absorbed them' (Meek 1962, p. 269). Something similar may be said about Forbonnais: in his case too any inspiration he may have drawn from Cantillon's Essai did of course not prevent him from developing his own theories, serving their own purposes. Indeed, the more interesting issue here is how apparently Forbonnais and Quesnay drew on different aspects of Cantillon's writings on circulation.

It is known that in the late 1750s the two men made their acquaintance and that initially relations were amicable. It is fascinating to see that in two surviving letters from Quesnay to Forbonnais, the conception of circulation figures prominently. ${ }^{82}$ In the second one ${ }^{83}$, dated 14 September 1758 , Quesnay wrote:

What you have written to me of your ideas about circulation has pleased me very much; it is the only way to conceive of it, in reality and in truth. Because the simple circulation of money [la simple circulation de l'argent] means nothing with regards to the knowledge of the wealth of a State, or to the produce of trade [...] Traded wealth is merely a stream of wealth that is forever consumed and renewed through reproduction; it is the sales volume of this stream, permanent through its renewal, that one has to capture in order to evaluate the revenue stream of a State. [...]. By your system of circulation [votre systeme de circulation] you see everywhere in the movement of this circulation the first fund of wealth and its first price, which gives the sum of revenues of the State, and you distinguish it everywhere from the repetitions of that same price in the successive sales and purchases, whether in the payments of manufactures or the payment of foodstuffs, whether in reciprocal trade or in barter [:] this here is the true knowledge of circulation [la vraye connoissance de la circulation]. You therefore offer a new route down which nobody has traveled yet and which is nevertheless the only approach to investigating the truth that consists of these three points [:] that useable wealth is nothing but a stream of tradable commodities that are forever destroyed by consumption and forever renewed by reproduction; that what is revenue or gain for one part of the subjects is expenditure or deduction for others, no revenue for the State, but only distribution of revenues; and

\footnotetext{
82 These letters, dated 1 and 14 September 1758, were first published in 1958 and reproduced, with corrections to the transcription, in Quesnay (2005, ii, 1173-80). The editors surmise that it was Quesnay who initiated contact with Forbonnais earlier in 1758, through the intermediation of Etienne-Claude Marivetz (1731-1794) with whom Quesnay collaborated in writing Questions intéressantes sur la population, l'agriculture et le commerce, which was published in June 1758 (ibid. i, 332-3 and ii, 1173). In that piece there are references to Forbonnais's entry 'Culture de terres' in the Encyclopédie (ibid. 342) and his Recherches sur les finances (ibid. 342 and 378). The first letter starts with a mention of an earlier, unknown, letter from Forbonnais to which it is a reply.

83 In the first letter the following passage is found, which reminds of Cantillon's concern in Essai, part ii chapters 3 and 4, with establishing the proportion between the amount of money required for circulation and annual production: 'I leave here to one side the question of the greater or smaller [quantity] of coined silver in a kingdom, which must have a relation with the rapidity or slowness of its circulation [that is] required for the purchases and sales of labour or commodities according to their market value and their quantity, which alone really constitute the greater or lesser [amount of] annual wealth in a State, and not the greater or lesser rapidity or slowness of the circulation of the pecuniary mass [whether] more or less abundant' (Quesnay 2005, ii, 1174; my translation).
} 
that there are no revenues in the State apart from tradable natural produce, and the net profit of foreign trade (Quesnay 2005, p.1177-9; emphasis in the original, my translation).

Unfortunately, the contents of the prior letter from Forbonnais to which Quesnay was apparently responding here are unknown. For that reason it hard to judge how much of what Quesnay pretended to be his account of 'your system of circulation' was actually his own interpretation and development of ideas that Forbonnais supplied him with. But in any case it seems rather significant that these descriptions of the circular flow of incomes and goods came at the very time when Quesnay was working on his first Tableau. When the so-called 'Third edition' of the Tableau économique was distributed in the late summer or autumn of 1759 Forbonnais was probably amongst the select group of recipients (see ibid. i, 393). 84

In the years that followed the relations between the two authors deteriorated significantly, although the precise course of events that led to this is not very clear. Boyer (2017) has recently argued that parts of 'Grains', written by early 1757 at the latest, should be read as Quesnay's first attempt to present an alternative programme for France's economic revival to the commerce politique of Forbonnais. 85 If so, then the very appreciative tone of Quesnay's letters a year later suggests that the fundamental differences that were emerging in their visions did not immediately lead to a breakdown in friendly relations. ${ }^{86}$ When this did occur, however, it caused a sequence of wide-ranging and bitter exchanges between the two men and their respective supporters. ${ }^{87}$

What is striking about Forbonnais's frontal assault on Quesnay's doctrines, his Principes et Observations CEconomiques of 1767, is the extent to which he presented his own views as an alternative understanding of the fundamental conception of circulation. This is particularly evident from the first part in which

\footnotetext{
${ }^{84}$ Forbonnais (1767, i, 161-2) would provide what long remained the most detailed description of this publication. In 1905 it provided Schelle with confirmation that he had found a 'third edition' (see Meek 1962, p.127). Subsequently Kuczynski rediscovered it, as recounted in Kuczynski and Meek (1972). Somewhat oddly Forbonnais stated that this edition, which he presumed to have been the first one, was published ' 5 or 6 years' earlier. This dating makes sense if Forbonnais already wrote his Principes in 1765, as argued by Orain (2012, p.87). It may also be noted that Forbonnais actually used for his discussion of the technical details of the Tableau the version that appeared in the sixth part of L'Ami des hommes, which was published in 1760 (see van den Berg 2002, 312 n.20).

${ }^{85}$ Boyer's argument is well made and he is careful to acknowledge that in 'Grains' Quesnay's views were still in a formative phase. Meek (1962, p. 267) argued similarly that between Quesnay's writing of 'Fermiers' and 'Grains' a crucial 'change of atmosphere' occurred, but, different from Boyer, he ascribed this more specifically to the influence of Cantillon. In Meek's view this influence of the Essai on Quesnay's writings was most pronounced in 'Grains', 'Hommes' and 'Impôts', all probably written in 1757 (see Quesnay 2005, p.213). For a similar interpretation see McNally (1988, pp.104-5).

86 Weulersse (1910, i, p.122) notes that as late as 1764 a letter written by Forbonnais about the grain trade that had been published in the Gazette du commerce was taken by Dupont as support for the physiocratic position when he included it in his Exportation des grains.

87 This is not the place to reconstruct the full details of a crucial polemic that was mostly fought out in the journals. For some of the contributions by supporters of Forbonnais and the man himself see van den Berg (2002, 312 n.28). For responses by physiocratic authors, including Quesnay himself see Quesnay (2005, ii, 1115ff).
} 
Forbonnais prepared his detailed critique of Quesnay's various writings later in the work by first systematically setting out his own views. ${ }^{88}$ After three short introductory chapters this part divided into chapter 4, pp. 14-101, entitled De la circulation simple ou par voie d'échange and chapter 5, pp. 102-160, De la circulation composée, où l'argent intervient. Thus from being largely confined to a single chapter in Elémens du commerce now the analysis of the economic system in terms of processes of circulation took over almost completely. It is important to note that in their general outlines the views Forbonnais presented here about the economic process-as-a-whole were not so very different from Quesnay. That is to say, he explained that the original spenders in the economy were the landowners, who had gradually extended the range of their needs beyond basic or 'real' subsistence needs and in this process had created reciprocal dependencies between themselves and all producers in society who supplied those needs.

The distribution of payments by the owners of the land can either consist in the customary real [payment] of a certain quantity of commodities, or in a quantity of money that has been established as medium for the evaluation of barter [; either way] he who receives the reward for his services [to the landowners] finds himself in the position to reward others of whom he stands in need. It is this reciprocal communication, either by commodities or by their signs, that constitutes commerce or circulation, either within a country or abroad (Forbonnais, 1767, i, 13).89

This summary statement of the meaning of circulation did not only share basic characteristics with Quesnay's overall vision, it was of course also reminiscent of Cantillon..$^{90}$ This was underscored by a footnote in which Forbonnais pointed out that some 'Ecrivains aconomiques' had recently started objecting to the use of the word commerce, because they understood by it only the activities of merchants. This amounted to ignoring that the word commerce in general [commerce en général] has always been understood to comprise all the things that men are capable of exchanging'. If nevertheless another 'generic word' was preferred, he suggested '[...] then one should use the word circulation' (ibid. n. e).

The phrase commerce en général called to mind the title of Cantillon's Essai and might well have had this very effect on contemporary readers. Indeed, even though Forbonnais nowhere named that work or its author, there were a number

\footnotetext{
${ }^{88}$ Each of the two volumes of this long work had two parts. Part one, volume one (pp. i-iii, 1-160) had the same title as the work as a whole. Part two, volume one (pp. 161-338) was entitled Observations sur le Tableau OEconomique. Part three, volume two (pp.1-242) was called Observations sur divers points du sistême contenu dans les articles Grains \& Fermier de I'Enciclopedie, dans le prétendu Extrait du CEconomie Rö̈ales \& ailleurs. Finally the shorter part four, volume two (pp.243-284), was a Précis historique du Cadastre dans le duché de Milan.

89 'La distribution des salaires par les propriétaires des terres, peut consister dans une tradition réelle d'une certaine quantité de denrées, ou dans une quantité de monnoïe établie pour être le moïen terme d'évaluation des échanges' [...] 'celui qui reçoit la récompense des ses services se trouve en état de récompense lui-même ceux dont il a besoin. C'est cette communication réciproque, soit des denrées soit de leurs signes, qui constituë le commerce ou la circulation, soit dedans d'un païs, soit au dehors'.

${ }^{90}$ At the risk of reading too much into this passage, there are elements that are especially reminiscent of Essai I, xiv, 1-2 (Cantillon 2015, p.132 [E139-140]). For example, the peculiar expression that landowner may pay his workers according to 'une tradition réelle d'une certaine quantité de denrées' may echo the customarily determined payments by the land owner to his workers before the introduction of money assumed by Cantillon in E139.
} 
of passages in this part that bore an unmistakable imprint of Cantillon. ${ }^{91}$ They included the distinction between 'intrinsic value' [valeur intrinsèque] and 'current value' [valeur courante] (Forbonnais 1767, i, 27; cf. i, 124) ${ }^{92}$; a discussion of the close relations between the food supply and the size of the population (ibid. i, 3946) ${ }^{93}$; the idea that a nation gains in foreign trade when exchanging products that have required the use of less land for products requiring more land (ibid. i, 60, 61) ${ }^{94}$; and the view that the export of manufactures allows a state to maintain 'a surplus of population above its natural or accidental proportion' (ibid. i, 66-7). ${ }^{95}$

The division of the first part of Principes into a description of economic circuits in terms of 'simple circulation' and of 'compound circulation', while reminiscent of the Elémens (above p.15), this time signified something different. By 'simple

${ }^{91}$ Given our thesis that Forbonnais had had access to Cantillon's work even before its publication in print, the fact that a copy of the Essai was present in Forbonnais's library is perhaps not so crucial, although still noteworthy. See Morrisson (1967, p.23 n.7) and Alimento (2006).

${ }^{2}$ Also: 'Lorsqu'il se sera formé des proportions générales de compensation intrinsèque entre les denrées, les variations qui surviendront sur chacune produiront cherté ou bas prix. La denrée chere se balancera avec une plus grande quantité d'autres denrées que de coutume; dans le bas prix avec une moindre quantitê. ['When general proportions of intrinsic repayments have established themselves between the commodities, the variations that occur to any of them will cause high or low prices. The expensive commodity will balance itself to a greater quantity of the other commodities than usual; the cheap one to a lesser quantity'. Admittedly, Forbonnais does not adopt Cantillon's notion of intrinsic value more specifically, that is, by explaining it in terms of quantities of land used. But the description of variations of the prices of commodities around their intrinsic values are surely close enough to Cantillon (2015, p.96 [E74]) to be confident that this is not a coincidence. By the way, Forbonnais had already used the term 'intrinsic value' on a few occasions in Elémens (see Forbonnais 1754b, i, 329, 350 and ii, 269), but apart perhaps from the first of these three instances the meaning he had then conveyed by that term differed from Cantillon's usage.

${ }^{93} \mathrm{He}$ argued that if the population of a country exceeds the food supply, then periodically part of the population will die of hunger, adding in a footnote 'this is what happens from time to time in China, and this is what produces a great crime against nature'. The latter appears to be a reference to infanticide, which also occurs in Cantillon (2015, p.140 [E151]). Admittedly, this observation about China was common during the $18^{\text {th }}$ century (see ibid. 141, [C151ii and iii) and might also owe something to Melon (1736, pp.382-9). For a longer discussion van den Berg (2016, p.6-13). Also see Forbonnais (1767, i, 46): 'dans un païs isolé il y auroit entre le nombre des hommes attachés à la production territoriale quelconque \& la population un rapport nécessaire \& qui existera aussi longtems que l'état de la production restera le même'. ['In an isolated country there would be a necessary ratio between the number of men attached to agricultural production of any kind and the [total] population and it would exist as long as the state of production will remain the same'].

94 'Ainsi une société gagne si elle parvient à retirer d'une moindre étenduë de terrain, la même quantité de productions emploïées dans ses échanges avec l'étranger: \& elle perd au contraire si elle vient à employer une plus grande étenduë de terrain pour échanger la même quantité de productions étrangeres'. ['Thus a society gains if it manages to draw from a smaller extent of land, the same quantity of products employed in its foreign trade; and, on the other hand, it loses if it manages to use a larger extent of land to exchange the same quantity of foreign products']. Similarly the discussion of this same theme on pages 125-7 of volume 2 is strongly reminiscent of Cantillon (2015, 356 [E487]). In Philosophie rurale (1763, 141-2) Mirabeau and Quesnay had explicitly rejected Cantillon's argument that a country that specialized in labour intensive manufactures would benefit in foreign trade with a country that specialized in 'land intensive' agricultural products (see Cantillon 2015, p. 367). Forbonnais, without naming Cantillon explicitly, here sided with him.

95 'un excédent de population au-delà de sa proportion naturelle ou accidentelle'. Cf. Cantillon (2015, p. 156 [E179]). 
circulation' Forbonnais now meant a hypothetical barter economy. 'Compound circulation' then described the same economy once money was introduced. The principal aim of this elaborate approach was to establish in what precise ways money made a difference. Arguing, as in earlier writings, that in many respects money, when considered as a mere intermediary medium of exchange, did not have independent effects on circulation, Forbonnais highlighted that the introduction of money did nevertheless bring about two major 'modifications [that are] alien to the natural order' (Forbonnais 1767, i, 102). ${ }^{96}$

The first reason why money mattered was that increases in the amount in circulation did stimulate economic activity. Especially when a nation experienced a steady inflow of money due to a positive balance of trade, then

commodities do not all rise in price at one and the same time; competition moderates profit; and profit gives rise to new products in a way that the quantity of commodities increases in proportion to the growth in the mass of money, especially in a country where much is left to be done (ibid. i, 132). ${ }^{97}$

Second, the introduction of money made it possible to lend and to borrow, which meant that 'money now produced a revenue to its owner. Therefore it has, in a fictitious manner, usurped the quality of immeuble and of wealth' (ibid. 107).98 While this revenue was all too real to the parties involved in loan contracts, it was fictitious to society as a whole, since the money by itself did not create the revenue, and interest payments only involved a transfer of income from borrowers to lenders. As to the question what ruled the interest rate on money, Forbonnais asserted:

In any country where there would be no public borrowing, the profit of money would be ruled by the nature of things itself upon a footing proportioned to the profits of agriculture and industry (ibid. 108, emphases added). ${ }^{99}$

The reason for Forbonnais to revisit these ideas about monetary circulation from his previous writings was to employ them in his critique of Quesnay's alternative analysis of circular flow. His most fundamental problem with the Tableau was that it was too abstract: the économistes had 'conceived of an ideal circulation that

\footnotetext{
96 'modifications étrangères à l'ordre naturel

97 'toutes les denrées ne haussent pas de prix à la fois; la concurrence modère le bénéfice; \& le bénéfice occasionne de nouvelles productions; de manière que la quantité des denrées s'étend en raison de l'accroissement de la masse numéraire, surtout dans un païs où il y a beaucoup à faire'. The final phrase was further emphasized in a note on p. 135: 'One of the major reasons that have led some Authors to regard the acquisition of money as unfortunate [fâcheuse] is that it would destroy production by making commodities more expensive. Those persons have not understood the difference between a country that cannot improve itself further and one that can'. It should be noted that very similar comments can be found in the 'reflections of the translator' of a new translation of Hume's Political Discourses of 1767.

98 'l'argent a produit un revenu à son propriétaire. Il a donc usurpé par fiction la qualité d'immeuble \& celle de richesse'. Here the word immeuble clearly did not have the modern French meaning of 'building'. Rather Forbonnais probably attached to it the more abstract meaning of 'a thing that does not move', which fits well with his earlier views on money hoarding. See above p.21.

99 'dans tous païs où il n'y auroit pas d'emprunts publics, le profit de l'argent seroit réglé par la nature même des choses sur un pied proportionné aux profits de la culture \& de l'industrie'.
} 
supposes societies approaching a purely natural state; and having arrived at principles that are essentially true, they have been unable to bring in modifications which alone could make those principles applicable to facts' (ibid. 217). For one thing, they had simply assumed that the amount of money required for circulation would have to be equal to the size of the produit net (ibid. 211). The problem with this was not so much whether this amount was wrong or right, but that it dispensed with an examination of the factors that actually determined the speed with which money circulated. ${ }^{100}$

In addition, Quesnay had simply assumed away that money, besides being a medium of circulation, had the function of immeuble fictive, or store of value (ibid. $213,215)$. This was extremely naïve because it completely ignored the fact that 'money is the sinew of war and of politics' (ibid. 215, cf. p.288). Being able to rely on money hoards for public borrowing was essential in a world where nations had to be able to defend their commercial interests and guarantee uninterrupted trade (see ibid. 290). It was one of the reasons why the physiocrats' famous impot unique on the net product of land was utterly unrealistic. Undoubtedly with the victorious nation in the seven years' war in mind, Forbonnais pointed out that 'the way war is fought these days in Europe, requires extraordinary efforts that no nation can support by its natural revenues, that is to say by taxes that are proportioned to the national revenue or to the net product' (ibid. 289). Even though 'the tableau oeconomique has not shown us yet a procedure to arrive at universal peace' (ibid. 290) its authors somehow presumed some kind of natural harmony between nations. ${ }^{101}$ But in reality France needed 'a navy to safeguard the same sales during war as during peace, without which taxes cannot be supported at the same level, nor credit maintained at a reasonable price' (ibid. 293).

With regards to the wealth that a nation was able to gain by foreign trade, Forbonnais spelled out some clear differences too. He accused the économistes of having invented the notion that any economic writer but themselves suffered from a bullion illusion, considering only money as wealth. In fact, however, there was no disagreement possible about the fact 'that money cannot constitute the fundamental power of a state; that in a state without mines, [money] can only

\footnotetext{
100 This speed with which money 'returned to the distributors of the original revenue' (i.e., the landowners) depended for example on how far away from their lands, where the rents were produced, the grands propriétaires lived and spent these incomes, and how quickly or how slowly the state spent the tax income it raised (Forbonnais 1767, i, 212). As we saw (n.83 above) in 1758 Quesnay still appeared to agree with Forbonnais that it would be difficult to put a value on the amount of money required for circulation but by the time he had produced the 'Third edition' he had settled on the assumption that this amount would be equivalent to the size of the produit net (Quesnay 2005, p.418; English translation in Meek 1962, p.134).

${ }^{101} \mathrm{He}$ argued that 'the conclusion of the system [of the rural philosophy] is that one should not fight offensive wars; but at the same time they acknowledge [the need for] a system of equilibrium [between nations]. Yet to maintain [such an equilibrium] one has to protect and support [one's interests] in an offensive manner; and a state that would never be on the offensive would forever be forced onto the defense' (Forbonnais 1767, i, p.294). He sarcastically advised the économistes to organize a 'perpetual congres' between nations in which they could impartially settle disputes. Elsewhere (ibid. i, p.55, 69, 113, 148) he offered a number of interesting reflections on the cosmopolisme of the physiocrats. Since the natural state of international relation was one of 'suspicion and anxiety', it was not realistic 'to administer the economic matters of a state that has external relations according to the sole principles of the natural order of things'.
} 
enter through the sale of products [and] hence production is the capital object' (ibid. 288). But, according to Forbonnais, Quesnay had all too easily rejected the stimulating real effects that the steady inflow of money into a country had. ${ }^{102} \mathrm{He}$ summed up his position as follows:

It is therefore true that the advantage of foreign trade does not consist uniquely in the increase of pecuniary wealth; but at the same time it is false [to say] that that increase is not a very great advantage. It is very precious because in a country where its natural influence is not obstructed, it tends to continually excite production and population. (Forbonnais 1767, ii, 144; emphasis in original).

\section{Conclusion}

Three long decades after his polemic with the économistes and nearly half a century after the publication of his Elémens du commerce, on 27 Prairial year VIII (16 June 1800), Forbonnais was received as an associate member of the Class of Moral and Political Sciences of the Institut National. ${ }^{103}$ Now an old man and terminally ill, his reception was mostly a geste to honour his long literary career. Tellingly, for his final lecture delivered on this occasion, Forbonnais chose to revisit a central theme of his previous writings, namely the Analyse des principes sur la circulation des denrées, et l'influence du numéraire sur cette circulation ('The Analysis of the Principles of the Circulation of Commodities and the Influence of Money on that Circulation').

Although acknowledging that conceptions of circulation had 'since long been the topic of various dissertations' (Forbonnais 1800, p.5), he did not name any of the great names that had in his day been associated with the analysis of circular flow. There was no mention of Quesnay, whose doctrines had at the dawn of the $19^{\text {th }}$ century lost most of their popularity, nor of Cantillon, whose Essai was by then all but forgotten. It was nevertheless in the context of the writings of those two theorists that Forbonnais's ideas on circulation can best be understood. The interpretation offered in this paper, that Forbonnais, like Quesnay, had originally drawn inspiration from Cantillon's depictions of circular flow, is not contradictory. It simply acknowledges that the Essai, like any inspirational work, was open to divergent readings and different creative elaborations. ${ }^{104}$

Generally speaking, Forbonnais seems to have been influenced primarily by the more specific monetary aspects of Cantillon's analysis of circulation, which reinforced his views about what would much later be called the 'non-neutrality' of

\footnotetext{
102 In Grains, for example, had done this by willfully using Spain as an example of a nation that had seen a huge inflow of precious metals without it resulting in a prosperous economy. This according, to Forbonnais, proved nothing because 'nobody is ignorant that the effects of money introduced in a country by labour are very different from the effects of money introduced by the excavation of mines' (Forbonnais 1767, ii, 137-9)

${ }^{103}$ For a book-length study of this Class see Staum (1996).

104 Of course Forbonnais and Quesnay were not be the only significant French readers of the Essai. Other interpretations, more interesting for aspects that are not the topic of the current paper, were given for example by the brothers Mably and Condillac.
} 
money. That is to say, Cantillon's qualifications of the quantity theory of money in the Essai with its careful consideration of the sequential propagation of changes in the money supply throughout the domestic economy was something that remained a recurrent theme in Forbonnais's works from 1754 onwards. In his final lecture, still, he insisted that 'the introduction of new money necessarily transmits a stimulating effect [un mouvement vivifiant] on those who receive it' (ibid. 14).

In addition, the view about interest rates as being determined within a separate circuit that temporarily took money and spending power out of the economy perhaps also took its first inspiration from Cantillon. However, the strong insistence that interest rates were in practice related to the political phenomenon of a well conducted management of public credit, and were determining, rather than being determined by, the rates of profit earned in productive activities, was Forbonnais's own.

Quesnay, by contrast, had been taken mostly with the real aspects of Cantillon's analysis, that is, the circulation of agricultural produce and incomes between social 'classes' in an annual cycle that started with the landowners spending their rents. The close association of these rents with the concept of a nation's produit net and the related defense of the notion of agriculture as the sole 'productive' sector were Quesnay's. The same can be said both for numerous technical details of the Tableaux and the dogmatic advocacy of sacred property rights and laissezfaire policies. ${ }^{105}$

Eventually, of course, Quesnay's views had much the more enduring impact on later developments in economic theory. In that context it was crucial that in Quesnay's hands circular flow analysis became centered on reproduction and the consumption and replacement of avances. But, as Forbonnais's long ignored alternative usage of Cantillon's analysis shows, a fuller history of the transmission and transmutation of ideas about 'circulation' requires that one does not stick to Schumpeter's 'one strong and simple line of development'. Instead this history took a more intricate route, moving, to borrow a metaphor from Cantillon himself, through 'several rivulets' of influence.

\section{Acknowledgments}

I thank the participants in the session at the ESHET conference in Madrid at which this work was first presented, especially Gianni Vaggi, Gabriel Sabbagh and Margaret Schabas for their comments. I also thank the two anonymous referees of my paper for their suggestions. Any remaining errors are my own.

105 The latter difference between Quesnay and Cantillon is spelled out in detail in a fascinating long letter from Dupont to Schlettwein (dated 16 September 1771) after the latter had had the temerity to name Cantillon's work, and that of Davenant, in the same breath as the works of the économistes. (See document W2-4582 at the Hagley Museum and Library, Wilmington, Delaware). I thank Gabriel Sabbagh for bringing this letter to my attention. 


\section{References}

Alimento, A. 1985. 'Véron de Forbonnais tra Spagna, Francia e Lombardia', Annali della Fondazione Luigi Einaudi 19, 171-94.

Alimento, A. 2006. 'Passione e disincanto nella vita di un economista "scomodo": la bibliotheca di Véron de Forbonnais', in C. Mangio and M. Verga (eds) II Settecento di Furio Diaz. Pisa: Pisa University Press.

Alimento, A. 2013. 'La concurrence comme politique moderne', in J. Astigarraga and J. Uzos (eds.) l'Économie politique et la sphère publique dans le débat des Lumières. Madrid: Casa de Velázquez.

Alimento 2014a. 'Translation, Reception and Enlightened Reform: The Case of Forbonnais in Eighteenth-Century Political Economy, History of European Ideas 40, 8, 1011-25.

Alimento A. 2014b. 'Beyond the Treaty of Utrecht: Véron de Forbonnais's French Translation of the British Merchant (1753)', History of European Ideas 40, 8, 1044-66.

Anonymous 1757. '[Review of] Great Britain's True System', Monthly Review, Or, Literary Journal. Volume 16, February, 105-113.

Anonymous 1759a. 'Catalogue raisonné des meilleurs Ouvrages concernant le Commerce', Journal de Commerce (January) 23-51

Anonymous 1759b. '[Review of] Great Britain's True System, Journal de Commerce (December) 134-158. Anonymous 1767. The General Principles of Commerce. Part 1 [n.p]. Aspromourgos, T. 1989. 'The Theory of Production and Distribution in Cantillon's Essai,' Oxford Economic Papers, 41, 356-73.

Benitez-Rochel, J. and Robles-Teigeiro, L. 2003. 'The foundations of the Tableau économique in Boisguilbert and Cantillon', European Journal of the History of Economic Thought, 10, 2, pp. 231-48.

Boyer, J.-D. 2017. Fermiers et Grains: deux moments de confrontation de Quesnay à la science du commerce, Cahiers d'Économie Politique, 2, 31-65. Blaug, M. 1962. Economic Theory in Retrospect. Homewood: Irwin. Brewer, A. 1988. 'Cantillon and Mercantilism', History of Political Economy20, 3, 447- 60.

Brewer, A. 2001. 'Introduction', Richard Cantillon. Essay on the Nature of Commercie in General. New Brunswick and London: Transaction Publishers. Pp. vii-xxvi.

Brewer, A. 2005. 'Cantillon, Quesnay and the Tableau Economique', Discussion Paper 05/557, October. Bristol University.

Cantillon, R. 2015. Richard Cantillon's Essay on the Nature of Trade in General. A variorum edition. R. van den Berg (ed.). London and New York: Routledge. Chamley, C. 2011. 'Interest Reductions in the Politico-Financial Nexus of Eighteenth- Century England', The Journal of Economic History, 71, 3, pp. 55589.

Charles, L. 2006. L'économie politique française et le politique dans la seconde moitié du XVIII" siècle', in: P. Nemo and J. Petitot (eds.) Histoire du libéralisme en Europe. $\quad$ Paris: Presses Universitaires de France. 279-312.

Charles, L. 2008. 'French "New Politics" and the Dissemination of David Hume's Political Discourses on the Continent, 1750-70', in C. Wennerlind and M. 
Schabas (eds.) David Hume's Political Economy. Abingdon and New York: Routledge. 181-202.

Charles, L. 2011. 'Le cercle de Gournay: usages culturels et pratiques savantes', in: $\quad$ Charles, Lefebvre, and Théré 2011, 63-87.

Charles, L., Lefebvre, F. and Théré, C. (eds) 2011. Le Cercle de Vincent de

Gournay. Savoirs économiques et pratiques administratives en France au

milieu du XVIIIe siècle. Paris: $\quad$ INED

Dangeul, L.-J. Plumard de, 1754a. Remarques sur les avantages et les

désavantages de la France et de la Grande Bretagne, par rapport au Commerce, \& aux autre Sources de la Puissance des Etats. Traduction de l'Anglois de Chevalier John Nickolls. 'Leyde'.

Dangeul, L.-J. Plumard de, 1754b. Remarks on the advantages \& disadvantages of France \& of Great Britain with respect to Commerce and to the other means of encreasing the Wealth \& Power of a State. Being a (pretended) translation from the English, written by Sir John Nickolls and printed at Leyden 1754. Translated from the French original. London: Osborne.

Demals, T. and Hyard, A. 2015. 'Forbonnais, the two balances and the Économistes', The European Journal of the History of Economic Thought, 22, 3, 445-72.

Duflos de Saint-Amand, D. 2011. 'Du problème de la légitimité de l'intérêt dans les articles de l'Encyclopédie rédigés par Véron de Forbonnais', in: Charles, Lefebvre, and Théré 2011, 239-258.

Eriksen, CB 2017, 'Circulation of Blood and Money in Leviathan - Hobbes on the Economy of the Body' in J Bek-Thomsen, C Olaf Christiansen, S Gaardsmand Jacobsen \& M Thorup (eds), History of Economic Rationalities: Economic Reasoning as Knowledge and Practice Authority. Springer, Ethical Economy. Studies in Economic Ethics and Philosophy, pp. 31-41.

Espinas, A. 1891. Histoire des doctrines economiques. Paris: Armand Colin. Flandreau, M., Galimard C., Clemens J., Nogués-Marco P., 2009. 'The Bell Jar: Commercial Interest Rates between Two Revolutions, 1688-1789', in J.

Atack and L. Neal (eds). The Origins and Development of Financial Markets and Institutions: From the Seventeenth Century to the Present. Cambride and New York: CUP, 161- 208.

Fleury, G. 1915. François Véron de Fortbonnais. Sa famille, sa vie, ses actes, ses œuvres 1722-1800. Mamers: Fleury.

Forbonnais, F. Véron Duverger de, 1753a. Opuscules de M. F*** Tome III contenant Un Extrait Chapitre par Chapitre du Livre de L'Esprit des Loix... Amsterdam: Arkstée \& Merkus.

Forbonnais, F. Véron Duverger de, 1753b. Théorie et pratique du commerce et de la marine. Paris Estienne.

Forbonnais, F. Véron Duverger de, 1753c. Le Négotiant anglois. Dresden:

Estienne.

Forbonnais, F. Véron Duverger de, 1753d. Various entries in D. Diderot and J. Le Rond D'Alembert (eds) Encyclopédie volume 3.

Forbonnais, F. Véron Duverger de, 1753e. Considérations sur les Finances

d'Espagne. Dresden [Paris].

Forbonnais, F. Véron Duverger de,1754a. Elémens du commerce. First edition. 
Forbonnais, F. Véron Duverger de, 1754b. Elémens du commerce. Seconde edition. à Leyde et se trouve à Paris.

Forbonnais, F. Véron Duverger de, 1755. 'Especes' entry in D. Diderot and J. Le Rond D'Alembert (eds) Encyclopédie volume 5.

Forbonnais, F. Véron Duverger de, 1758. Recherches et considerations sur les finances de France depuis l'année 1595 jusqu'à l'année 1721. Basel: Cramer. Forbonnais, F. Véron Duverger de, 1767. Principes et Observations OEconomiques. Amsterdam.

Forbonnais, F. Véron Duverger de, 1800. Analyse des principes sur la circulation des denrées, et l'influence du numéraire sur cette circulation. Paris: Veuve Devaux. Foley, V. 1973. 'An origin of the Tableau Économique', History of Political Economy, 5, 1, 121-150.

Goudar, A. 1756. Les intérêts de la France mal entendus. Amsterdam: J. Coeur. Vol.3.

Gournay, J.C.M Vincent de [1752] 1983. Traité sur le commerce de Josiah Child avecles Remarques inédites de Vincent de Gournay. T. Tsuda (ed.) Tokyo: Kinokuniya.

Gournay, J.C.M Vincent de [1752] 2008. Traités sur le commerce de Josiah Child. Suivis des Remarques de Jacques Vincent de Gournay. S. Meyssonnier (ed.) Paris: L'Harmattan.

Groenewegen, P.D. (ed.) 2001. Physicians and Political Economy. Six studies of the work of doctor-economists. London and New York: Routledge.

Guasti, N. 2014. 'Véron de Forbonnais and Plumard de Dangeul as Translators of Uztáriz and Ulloa', History of European Ideas, 40, 8, 1067-1086.

Harsin, P. 1928. Les doctrines monétaires et financières en France du XVIe au XVIIIe siècle. Paris: Félix Alcan.

Helvétius, C. A. 1773. De L'Homme, de ses facultés intellectuelles et de son éducation. Londres: La Société Typographique.

Higgs, H. 1892. 'Cantillon's Place in Economics', The Quarterly Journal of Economics, 6, 4, pp.436-56.

Hont, I. 2008. "The "Rich Country-Poor Country" Debate Revisited: The Irish Origins and French Reception of the Hume Paradox' in C. Wennerlind and M. Schabas (eds.) David Hume's Political Economy. Abingdon and New

York: Routledge. 243-323.

Hume, D. 1752. Political Discourses. Edinburgh: R. Fleming.

Hume, D. 1955. David Hume: Writings on Economics. E. Rotwein (ed). Madison: University of Wisconsin Press.

Hume, D. 1754. Discours Politiques de Monsieur Hume. Traduit de I'Anglois par Monsieur l'abbé Le Blanc. Amsterdam: Lambert.

Hume, D. 1767. Essais sur le commerce. Paris: Saillant, Lyon: Aimé Delaroche. Keynes, J.K. 1936. The General Theory of Employment, Interest and Money. 1973 edition. London and Basingstoke: Macmillan.

Kuczynski, M. and Meek, R. 1972. Quesnay's Tableau Économique. London: Macmillan.

Larrère, C. 1992. L'invention de l'économie au XVIII' siècle. Paris: Presses Universitaires de France. Law, J. 1714. 'Second mémoire sur les banques', in: E. Daire (ed), Économistesfinanciers $\quad d u$ XVIIIe siècle. 1843. Paris: Guillaumin. 
Lavergne, L. de 1870. Les économistes français du dix-huitième siècle. Reprint 1970. Geneva: Slatkine.

Le Maux, L. 2014. 'Cantillon and Hume on Money and Banking: The Foundations

of Two Theoretical Traditions', Economic Surveys, 28, 5, 956-970.

Maty, M. 1753. '[Review of] the Universal Dictionary Volume 1', Journal

Britannique, 12 (November-December), 243-61.

McNally, D. 1988. Political Economy and the Rise of Capitalism: A

Reinterpretation. University of California Press.

Meek, R.L. 1962. The Economics of Physiocracy. Reprint 1993, New York: A.M.

Kelley.

Meyssonnier, S. 1989. La Balance et l'Horloge. La genèse de la pensée libérale en

France $a u \quad X V I I I^{e}$ siècle. Montreuil: Les éditions de la passion.

Meyssonnier, S. 1990. 'Deux économistes libéraux sous la Révolution: Véron de

Forbonnais et l'Abbé Morellet', Economies et Sociétés 13, 109-21.

Meyssonnier, S. 2008. Traités sur le commerce de Josiah Child. Suivis des

Remarques de Jacques Vincent de Gournay. Paris: L'Harmattan.

Meyssonnier, S. 2011. 'Vincent de Gournay, un intendant du commerce au travail.

L'apport du fonds de Saint-Brieuc à l'intelligence de ses textes', in:

Charles, Lefebvre, and Théré (eds.) pp. 89-110.

Mirabeau, V. Riqueti, Marquis de 1760. Théorie de l'impôt [n.p]

Mirabeau, V. Riqueti, Marquis de 1763. Philosophie rurale ou Économie générale et politique de l'agriculture. Amsterdam: Les Libraires Associés.

Monroe A.E. 1923. Monetary Theory Before Adam Smith. 1966 Reprint. New

York: A.M. Kelley.

Morellet A.1769. Prospectus d'un nouveau dictionnaire de commerce. Paris:

Estienne.

Morellet A.1775. Réflexions sur les avantages de la liberté d'écrire et d'imprimer.

Paris: Estienne.

Morellet A. 1821. Mémoires sur le dix-huitième siècle et sur la révolution

française. Paris: Ladvocat

Morrison, C. and Goffin, R. 1967. Questions financières aux XVIIIe et XIXe siècles.

Paris: PUF.

Murphy, A.E. 1986a. 'Le développement des idées économiques en France (1750-

1756)', Revue d'histoire moderne et contemporaine, 32, 521-541.

Murphy, A.E. 1986b. Richard Cantillon: Entrepreneur and Economist. Oxford:

Clarendon Press.

Murphy, A. 1993. 'John Law and Richard Cantillon on the circular flow of income', The European Journal of the History of Economic Thought 1, 1, 47-61.

Nagels, J. 1970. Genèse, contenu et prolongements de la notion de reproduction du capital selon Karl Marx, Boisguillebert, Quesnay, Leontiev. Brussels: Editions de l'Institut de Sociologie de l'Université Libre de Bruxelles.

Orain, A. 2010. 'Progressive indirect taxation and social justice in eighteenth

century France. Forbonais and Graslin's fiscal system', The European

Journal of the History of Economic Thought. 17, 4, 659-685.

Orain, A. 2012. 'Graslin and Forbonnais against the Tableau économique (1767)',

in J. Cartelier and G. Longhitano (eds.) Quesnay and Physiocracy Studies and

Materials. Paris: L'Harmattan, pp.87-111. 
Orain, A. 2013. 'Soutenir la guerre et réformer la fiscalité: Silhouette et Forbonnais au Contrôle général des finances', French Historical Studies. 36, 3, 417-448.

Postlethwayt, M. 1751-5. The Universal Dictionary of Trade and Commerce, Translated from the French of the Celebrated Monsieur Savary. London: John and Paul Knapton.

Postlethwayt, M. 1757a. Great-Britain's True System. London: Millar, Whiston, White and Sandby.

Postlethwayt, M. 1757b. Britain's Commercial Interest Explained and Improved. In a Series of Dissertations on Several Important Branches of her Trade and Police. London: Brown, Millar, Whiston, White and Sandby. Quesnay, F. 2005. CEuvres Économiques Complètes et Autres Textes. C. Théré, L. Charles and J.-C. Perrot (eds.) Paris: INED.

Rist, C. 1938. Histoire des doctrines relatives au credit et a la monnaie, depuis John Law jusqu'a nos jours. Paris: Librairie du Recueil Sirey.

Sabbagh, G. 2016. 'Cantillon in French and English. Two editions by Richard van den Berg and Antoin E. Murphy: New facts and hypotheses', Contributions to Political Economy. 35, 1: 91-126.

Schumpeter, J. 1954. History of Economic Analysis. London: Allen and Unwin. Skornicki, A. 2006. L'État, l'expert et le négociant: le réseau de la "science du commerce" sous Louis XV', Genèses, 4, 65, 4-26.

Sonenscher, M. 2007. Before the Deluge. Public Debt, Inequality, and the Intellectual Origins of the French Revolution. Princeton and Oxford:

Princeton University Press.

Staum, M.S. 1996. Minerva's Message. Stabilizing the French Revolution.

Montreal: McGillQueen's University Press.

Steiner, P. 2011. 'Commerce, commerce politique' in: Charles, Lefebvre, and Théré 2011, 179-200.

Sutter, J. 1958. 'Quesnay et la médecine', in: François Quesnay et la Physiocratie. Paris: INED, pp. 197-210.

Thornton, M. 2007. 'Cantillon, Hume and the Rise of Antimercantilism', History of Political Economy, 39,3, pp.453-80.

Tsuda, T. 1979. Cantillon. Essay de la nature du commerce en général. Tokyo: Hitotsubashi University.

Tsuda, T. 1983. Traités sur le Commerce de Josiah Child avec les Remarques inédites de Vincent de Gournay. Tokyo: Kinokuniya.

Tsuda, T. 1993. Mémoires et Lettres de Vincent de Gournay. Tokyo: Kinokuniya. Tucker, G.S.L. 1960. Progress and Profits in British Economic Thought 16501850. Cambridge: CUP.

Turgot, A.R.J. 1770. Réflexions sur la formation et la distribution des richesses in: G. Schelle (ed.) OEuvres de Turgot et documents le concernant 1914, vol. 2, pp.533-601.

Van den Berg R. 2002. 'Contemporary responses to the Tableau Économique', in: S. Boehm, C. Gehrke, H. Kurz and R. Sturn (eds.) Is There Progress in Economics? Knowledge, Truth and the History of Economic Thought.

Cheltenham: Edward Elgar. 295-316.

Van den Berg, R. 2012. 'Cantillon's Early Monetary Views?', Economic Thought, 1(1), pp. 48-79. 
Van den Berg, R. 2014. 'Cantillon on Profit and Interest: New Insights from Other Versions of His Writings', History of Political Economy, 46, 4, 609-40.

Van den Berg, R. 2016. 'Chinese influences on the formation of classical political economy. Some critical reflections', Paper presented at the $48^{\text {th }}$ UK Conference at SUFE in Shanghai.

Van den Berg, R. 2017a. 'A judicious and industrious compiler: Mapping Postlethwayt's Dictionary of Commerce', The European Journal of the

History of Economic Thought, 24, 6, 1167-1213.

Van den Berg, R. 2017b. ' Fas est \& ab hoste doceri. Malachy Postlethwayt and the Gournay Circle', Paper presented at the $21^{\text {st }}$ ESHET Conference in Antwerp. Van den Berg, R. 2019. 'Turgot's Theory of Capital and Interest in its Contemporary Context', Paper presented at the HES Conference in New York.

Vauban, S. Le Prestre de 1691. 'Memoire sur le canal de Languedoc', in: Vauban. Sa Famille et ses Écrits. 1910. Paris: Berger-Levrault, Vol. 1.

Weulersse, G. 1910. Le Mouvement Physiocratique en France. Paris: Félix Alcan. Wennerlind, C. 2005. 'David Hume's Monetary Theory Revisited: Was he really a quantity theorist and an inflationist?', Journal of Political Economy 113, 1, 223-37.

\begin{abstract}
Circular flow analysis in mid-18 $18^{\text {th }}$ century France is normally associated with the writings of François Quesnay. From the early 1750s, however, François Véron de Forbonnais developed a distinct theory of circulation in then well-known contributions to the Encyclopédie and his Elémens du commerce of 1754. This article argues that like Quesnay, Forbonnais was in part inspired by Cantillon's Essay on the Nature of Trade in General. But while Quesnay gave original developments to the real aspects of Cantillon"s analysis of circulation, Forbonnais focussed on developing monetary aspects, including arguments for the 'nonneutrality' of money and an original theory of the money interest rate.
\end{abstract}

Keywords: Cantillon, Forbonnais, Quesnay, circular flow, non-neutrality of money

JEL codes: B11, E40 